\title{
Assessing the impact of oil-related activities on benthic macroinfauna assemblages of the Campeche shelf, southern Gulf of Mexico
}

\author{
Hector A. Hernández Arana*,1,4, Richard M. Warwick ${ }^{1,2}$, Martin J. Attrill ${ }^{1}$, \\ Ashley A. Rowden ${ }^{1,5}$, Gerardo Gold-Bouchot ${ }^{3}$ \\ ${ }^{1}$ Marine Biology and Ecology Research Group, School of Biological Sciences, University of Plymouth, Drake Circus, \\ Plymouth PL4 8AA, UK \\ ${ }^{2}$ Plymouth Marine Laboratory, Prospect Place, Plymouth PL1 3DH, UK \\ ${ }^{3}$ Centro de Investigación y de Estudios Avanzados del Instituto Politécnico Nacional (CINVESTAV-IPN), \\ Antigua Carr. a Progreso km 2.5, 97310 Mérida, Yucatán, Mexico \\ ${ }^{4}$ Present address: El Colegio de la Frontera Sur, Avenida Centenario km 5.5, Apartado Postal 424, Chetumal 77000, \\ Quintana Roo, Mexico \\ ${ }^{5}$ Present address: National Institute of Water and Atmospheric Research, PO Box 14-901, Wellington, New Zealand
}

\begin{abstract}
Considering the long history of oil extraction and the numerous platforms that exist in the southern Gulf of Mexico, a regional approach has been used to investigate the impact of oilrelated activities on the macrobenthic community. The objective was to determine the effect of oilrelated activity in a region known to have a highly variable benthic community composition due to temporal and spatial variability of its natural environment. A transect design along gradients of natural variables and disturbance intensities, including active oil platforms, was implemented during the rainy and winter storms ('northers') seasons of 1999 to 2000. Univariate and multivariate statistical analyses were applied to a data set of 2 macroinfauna size fractions retained on 0.5 and 2 mm sieves, in conjunction with levels of metals, oil hydrocarbons and a range of natural sediment variables. A pattern of contamination existed, with increased levels of contaminants at stations close to rigs and in areas of high oil platform densities. At these sites, macroinfauna abundance and biomass were reduced. Regression analyses and matching of Biotic to Environmental multivariate patterns (BIO-ENV) indicated that a combination of metals and natural sediment variables best explained the variability in macroinfauna data for all sites. Meta-analysis at phylum level was employed to specifically assess disturbance. The results of this technique were inconsistent between sampling dates due to a complex influence of natural and anthropogenic disturbance. However, increased variability in community composition was linked to oil-related disturbance.
\end{abstract}

KEY WORDS: Oil disturbance $\cdot$ Infauna $\cdot$ Carbonate-terrigenous sediments $\cdot$ Multivariate statistics Gulf of Mexico

Resale or republication not permitted without written consent of the publisher

\section{INTRODUCTION}

Natural disturbance of benthic communities can potentially mask the effects of contamination by offshore oil-related activities. Therefore, to identify disturbance of macroinfauna assemblages from offshore oil activities, suitable spatial and temporal designs that consider natural infaunal variability need to be employed (Clark
1982, Spies 1987). Background information, adequate controls and long-term monitoring, plus a combination of samples taken on a regional basis and along radial gradients around oil drilling sites or production platforms, are required to ensure sampling designs are adequate for studying oil-related effects on marine benthic assemblages (Carney 1987, Ellis \& Schneider 1997). Various sampling approaches have proved 
successful in the North Sea for detecting and monitoring the effects of offshore oil activities (Dicks 1976, Hartley 1984, Daan \& Mulder 1996). The main finding of these early oil-impact studies was that oil-related disturbance of benthic macrofauna assemblages was localised around the site of the oil platform; there was a severe reduction in fauna close to platforms (up to $200 \mathrm{~m}$ away from the platform), a peak in opportunist species 500 to $1000 \mathrm{~m}$ away and subtle effects detectable up to $2 \mathrm{~km}$ from the centre of the disturbance activity (Addy et al. 1984, Davies et al. 1984, Kingston 1992). Subsequent to these studies, effects of oil on macrofauna assemblages have been detected up to $6 \mathrm{~km}$ from platforms, suggesting that the local approach to studying oil-related disturbances was no longer suitable (Gray et al. 1990, Olsgard \& Gray 1995).

In contrast, studies of the northern Gulf of Mexico suggest that even the long-term effects of oil-related activities on the benthos are highly localised around the point source, where effects are only detectable up to $200 \mathrm{~m}$ from source (Middleditch 1981a, Montagna \& Harper 1996) and up to $800 \mathrm{~m}$ from produced water discharge points (Rabalais et al. 1992). However, major differences exist between the sampling carried out in the North Sea and the Gulf of Mexico; studies of oilrelated impacts in the latter region often lack background information and suitable controls (Green \& Montagna 1996). In addition, the impact of oil on the benthos in the Gulf of Mexico is potentially more chronic, as low levels of oil hydrocarbons are dispersed from natural oil seeps and non-natural sources of oil augmented by a longer history of oil exploitation (Spies 1987). Natural disturbances from river runoff, associated anoxia-hypoxia and differences in other major natural variables (e.g. depth and grain size) have also possibly hindered the identification of the generalised effects of oil-related activities on macrofauna assemblages in the northern Gulf of Mexico (Green \& Montagna 1996). In the southern Gulf of Mexico, no previous attempt has been made to evaluate oil-related influences on benthic infaunal assemblages (Vazquez et al. 2000), with the only available data coming from a single survey of a natural seep (Gonzalez-Macias 1989) and assessments of the effect of oil on shrimp populations (Soto \& Gracia 1987).

The southern Gulf of Mexico has combined influences from river runoff, winter storms ('northers') and a gradational sedimentary environment of terrigenous and carbonate sediments (Bello \& Cano 1991, FuentesYaco et al. 2001). Ecological research has emphasised that 'northers' and river runoff are the most important physical processes influencing large-scale benthic community structure, function and interactions across and along the carbonate and terrigenous shelves (Yañez-Arancibia \& Sanchez-Gil 1983, Soto \& Escobar-
Briones 1995, Hernandez-Arana et al. 2003). In addition, the presence of an extensive area of offshore oil production potentially contributes to changes in the structure of benthic communities (Vazquez et al. 2000). Further work is still required, however, in relation to smaller scales of spatial variation $(10 \mathrm{~s}$ to $<100 \mathrm{~km})$ and temporal changes in community structure and composition. This research needs to be focused along gradients produced by the river influence on the shelf and, particularly, its interaction with offshore oil activities in order to gather relevant information to differentiate between natural and anthropogenic disturbance.

The approach adopted for the present study is a regional one that involves sampling transects (on 2 occasions) along gradients of the main natural variables, encompassing sites both distant from, and close to, oil platforms. Thus, the study design attempts to accommodate spatial and temporal influences on assemblage composition due to natural disturbance from river discharges and storm events, and allows for the fact that oil-related effects might extend beyond the immediate area of a platform's influence. The sampling design also allows a concomitant consideration of the influence of oil platform density on the seabed assemblages. The hypotheses to be addressed were: (1) macroinfauna assemblages located in areas of high oil platform density will exhibit a different composition, and lower abundance and biomass than those in areas of low oil platform density or without oil-related activities; (2) macroinfauna assemblages located relatively near to an oil platform will exhibit a different assemblage composition, and lower abundance and biomass than those located relatively distant from oil platforms, similar to other oil-influenced continental shelves. Univariate and multivariate statistical techniques were employed to test these hypotheses. Temporal differences were expected as a result of natural disturbance from river runoff and storm events; however, it was expected that their influence would remain constant and independent of the impact derived from the oil-related activities.

In addition to formal hypothesis testing, the metaanalysis pollution impact assessment technique proposed by Warwick \& Clark (1993a) was utilised, and its validity for tropical environments evaluated. This technique was used to compensate for the lack of background information, long-term monitoring and valid spatial controls.

\section{MATERIALS AND METHODS}

Study site. The study location covers the area between $19^{\circ} 00^{\prime}$ and $19^{\circ} 40^{\prime} \mathrm{N}$ and $91^{\circ} 40^{\prime}$ and $92^{\circ} 30^{\prime} \mathrm{W}$, within the relatively homogenous, muddy, 'transi- 
tional' environment that occurs between the carbonate and terrigenous environments of the Campeche Bank and Bay (Fig. 1). The characteristics of these sediment provinces have been previously described (GutierrezEstrada \& Galaviz-Solis 1991, Hernandez Arana 2003). Discharges from the Grijalva-Usumacinta and San Pedro-San Pablo rivers, 'northers' and associated intrusion of oceanic water from the Caribbean current are the driving physical processes on the shelf (Monreal-Gomez et al. 1992, Vidal et al. 1994). The water circulation pattern is driven by the Caribbean current during the spring and summer, with a south to southwest direction, but during autumn and winter, the flow reverts to an east to north-east direction (Boicourt et al. 1998). Water column stability changes from stratified to homogenous between the 'rainy' and the 'northers' seasons, markedly affecting the inner shelf $(<30 \mathrm{~m}$ depth) (Czitrom et al. 1986). The study area includes the largest offshore oil production region of Mexico, covering an area of $8000 \mathrm{~km}^{2}$ that includes natural oil seeps and approximately 200 platforms with a range of functions (Valdes \& Ortega Ramirez 2000). Oil activities in the Campeche Bay have developed since 1974 with the discovery of several oil fields (Santiago \& Baro 1992). The world's largest offshore oil-related contamination event occurred in the Campeche Bay with the Ixtoc I production-well blowout in 1979 (Boehm et al. 1982, Botello et al. 1982). Subsequently, some relatively minor oil-spills have occurred in other oil fields in the area during 1986, 1987 and 1988 (LizarragaPartida et al. 1991).

Study design. The sampling design consisted of 2 across-shelf (A, B) and 2 along-shelf $(C, D)$ transects, following natural variations of depth, river runoff influence and depositional environment (Fig. 1). The original design for the across-shelf transects was to follow a depth gradient of 12 to $135 \mathrm{~m}$. Based on previous largescale studies, along-shelf transects were set to follow a sediment gradient from clay/clay silt to fine sand and carbonate content from 20 to $50 \%$, whilst depth was kept relatively constant (30 to $50 \mathrm{~m}$ ). Twelve stations, approximately 7 to $8 \mathrm{~km}$ apart, were allocated to each transect to represent the regional variation in macroinfauna assemblages and sediment types. Each pair of transects transversed the oil production zone, allowing a more intense sampling in the area of high oil platform densities. Information on the precise positions of oil platforms on the Campeche Shelf (Nautical chart SM 840, Secretaría de Marina 1994) and the spatial distribution of stations on the 2 transects allowed 2 different approaches for assessing oil-related influences. Firstly, stations along both transects could be partitioned according to the density of oil platforms within a putative distance of influence from the station and, secondly, their actual distance from oil platforms could be utilised. Due to the patchy distribution of platforms, oilrelated influences on the benthic assemblages might be a combination of proximity to an oil platform and the

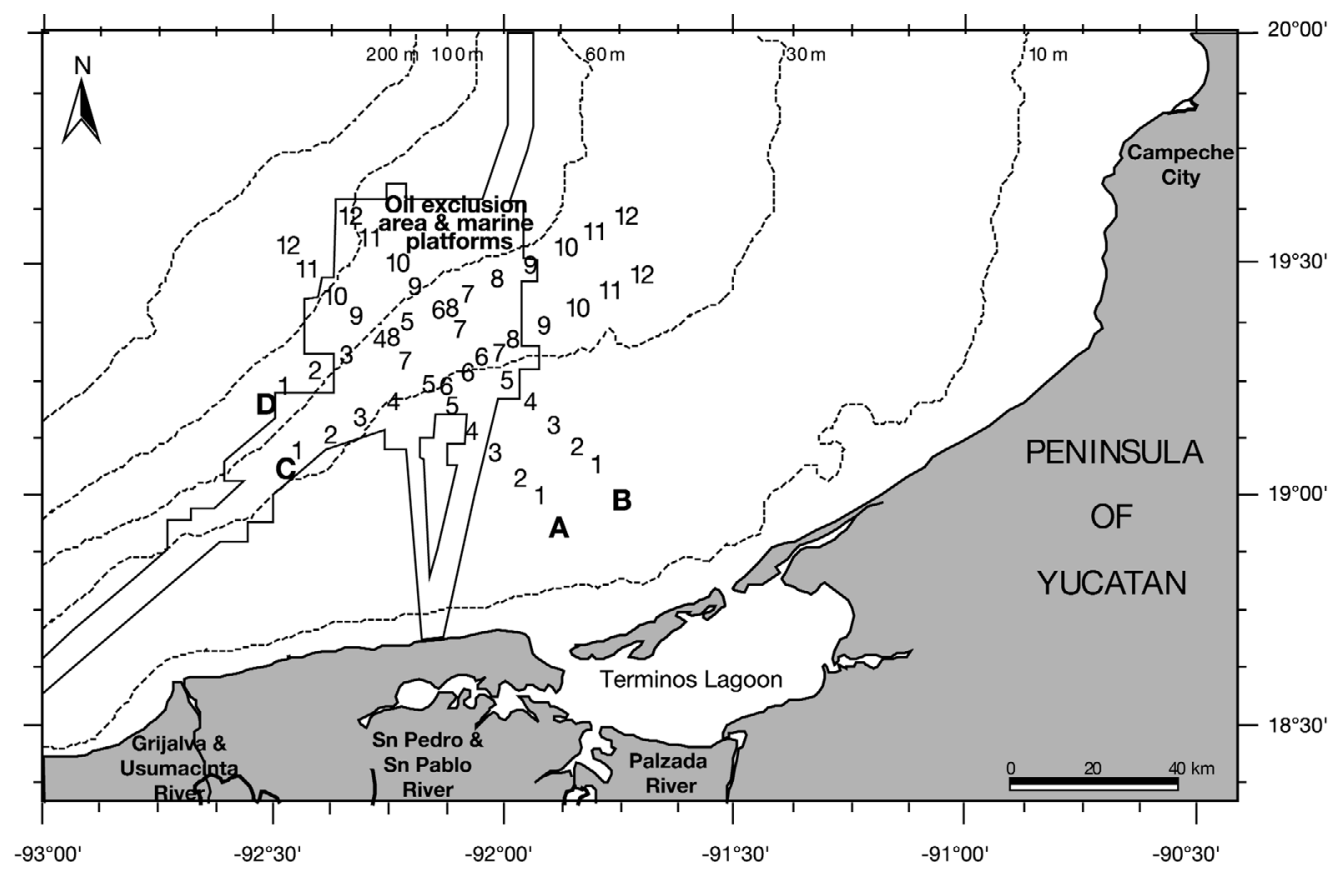

Fig. 1. Study area showing the location of stations along the 4 transects A to D in the southern Gulf of Mexico. The delimited polygon comprises the area of oil-related activities where fishing and commercial navigation is forbidden 
density of oil platforms within a putative radius of influence. Therefore, the influences of proximity and density of oil platforms need to be examined separately.

Sampling methodology. Sampling was carried out from 11 to 13 November 1999 after the 'rainy' season and from 14 to 16 April 2000 after the 'northers' season/beginning of the dry season. Stations were located and positioned using the satellite navigation system of the RV 'Justo Sierra' and sampled (without replication) using a box corer. Sample size was 0.14 and $0.23 \mathrm{~m}^{2}$ for November and April respectively, due to different box corers being available on each cruise. Additional information recorded included the water depth and bottom salinity from each station. The recovered core was sub-sampled for organic matter, carbonate content and grain size analysis. Such samples were taken using a PVC core of $10 \mathrm{~cm}$ in diameter to a depth of $5 \mathrm{~cm}$, transferred to a previously labelled plastic bag and frozen until analysis. Sub-samples for oil hydrocarbons and trace metals were taken using a Teflon $^{\mathrm{TM}}$ core of $15 \mathrm{~cm}$ in diameter to a depth of $5 \mathrm{~cm}$, which was then transferred to a high-density polyethylene plastic jar, labelled and frozen until analysis. Two size fractions of macroinfauna were sampled from each station, with the purpose of obtaining a better representation of the large infauna, but also to take into account the contribution of the smaller infauna that potentially survive better under stressful conditions (Warwick \& Clarke 1994). Small macroinfauna was sampled using a sub-core of $0.01 \mathrm{~m}^{2} \times 20 \mathrm{~cm}$ depth and sieved through a $0.5 \mathrm{~mm}$ mesh. Large macroinfauna was recovered from the remaining sediment after removing all the above samples, and sieved through a $2.0 \mathrm{~mm}$ mesh. Samples were fixed in $5 \%$ formaldehyde solution buffered in seawater and stained with Rose Bengal prior to initial storage. Due to technical difficulties a number of stations were not sampled (A2 and B1 in November 1999 and A4, A10, B3, C5, C7, D4 and D6 in April 2000, i.e. 2 and 7 stations out of 48).

Laboratory analyses. Macroinfauna samples were transferred to a $70 \%$ ethanol solution. Organisms were sorted, counted, wet weighed and identified to family level. Identification of the fauna to family level has proved to be sufficient for environmental studies in the southern Gulf of Mexico (Hernandez Arana et al. 2003) and other areas (Ferraro \& Cole 1992, Somerfield \& Clarke 1995). Organic matter content of sediment was measured using the ignition technique (Dean 1974). Carbonate content was analysed by acid digestion and titration (Holme \& McIntyre 1984). Grain size distributions were measured with a Malvern Mastersizer X laser particle sizer (Wolfe \& Michibayashi 1995) and descriptive statistics (mean grain size, sorting or inclusive standard deviation) calculated in phi units using the moment measure approach. Additional sediment data included the specific surface area of the sediments expressed as $\mathrm{m}^{2} \mathrm{~g}^{-1}$ and calculated as spherical theoretical proxies assuming a density of $2.65 \mathrm{~g} \mathrm{~cm}^{-3}$ for the sediment, and the percentage of sand, silt and clay.

Concentrations of iron, manganese, zinc, copper, nickel, chromium and barium were quantified by induction coupling to plasma emission spectroscopy. Samples were oven-dried at $50^{\circ} \mathrm{C}$ and then digested with $5 \%$ hydrochloric acid to extract the fraction of metals contained in the organic matter and soluble sediments (APHA 1985). Iron was used to normalise metal concentration following Macias-Zamora et al. (1999). Hydrocarbon analyses were undertaken using soxhlet reflux extraction for $12 \mathrm{~h}$ into dichloromethane, followed by clean up and fractionation through silica/ alumina gel column chromatography (Sericano et al. 1990, UNEP/IOC/IAEA 1992). The individual aliphatic (n-C10 to n-C34, pristane and phytane) and polycyclic aromatic hydrocarbons (PAH, 22 compounds) were identified and quantified by high-resolution gas chromatography (GC) using a Hewlett Packard HP5890 Series II with a flame ionisation detector. The measure of total hydrocarbons (TH) includes all resolved peaks of aliphatic and PAH hydrocarbons, and the area covered by the unresolved complex mixture (UCM). Concentrations of UCM and the fossil fuel pollution index were used to establish the origin of oil hydrocarbons (Boehm \& Farrington 1984, Volkman et al. 1992). To assure quality control, appropriate blanks and reference materials were analysed simultaneously with each batch of samples.

Data analyses. The individual matrices for small and large macroinfauna were standardised to $1 \mathrm{~m}^{2}$ and combined (allowing a representation of the overall size spectrum of the macroinfauna) into single matrices of abundance and biomass per sampling occasion (2 times). All the statistical analyses were undertaken using the combined data of small and large macroinfauna, because the separated analysis of the 2 fractions showed similar results (Hernandez Arana 2003) and also to incorporate the information provided by the larger macroinfauna in terms of its contribution to the biomass. Graphs of concentrations of total oil hydrocarbons (of which more than 90\% was an unresolved complex mixture) and metals along transects for each season were constructed in order to identify spatial patterns of possible contaminant distribution. Pearson's product-moment correlation coefficients were calculated for metals, oil hydrocarbons, depth, mean grain size and distance to oil platforms, to establish relationships with natural variables and sources of putative contaminants. The set of 23 environmental variables (natural and oil-related) from each season were subjected to principal component analysis (PCA) 
on a normalised correlation matrix after suitable transformation $\left(\log _{10}\right.$ for continuous measurements or arcsin transformation for variables expressed as a percentage).

Hypothesis 1. Influence of oil platform density: To test the hypothesis that stations located in areas of relatively high oil rig density present lower values of macroinfauna abundance and biomass, stations were grouped in relation to the number of oil platforms within a radius of $5 \mathrm{~km}$ : high density (4 to 12), low density (1 to 3 ) and no oil platforms (see Table 2 ). The distance of $5 \mathrm{~km}$ was chosen as this is the approximate distance up to which oil-related influences have previously been detected around oil platforms (Olsgard \& Gray 1995) and also to maximise the number of samples within each group. A 2-factor ANOVA balanced design was applied to test for differences in mean values of abundance and biomass between sampling dates and among oil platform densities for a randomly selected subset of 11 stations for each density. This analysis was followed by multiple linear regression analysis to estimate and fit a structural model to explain the variation in the observations of biological measures in terms of natural variables and concentrations of oil hydrocarbons and metals. Variables were checked for colinearity using the Pearson's productmoment correlation coefficients. Where a combined coefficient for a pair of variables was above 0.95 and significant at the $5 \%$ confidence level, one variable was not included in the regression analysis. Thus, the selected variables were water depth, mean grain size, $\%$ silt, sorting, \% organic matter, total hydrocarbons, iron, barium, chromium and nickel, the latter 3 normalised using iron. All variables were checked for normality using the Wilk's $\lambda$ and transformed when necessary either with $\log _{10}$ for continuous measurements or arc-sin transformation for variables expressed as a percentage (Sokal \& Rohlf 1995).

Hypothesis 2. Influence of distance to oil platform: To test the null hypothesis of no difference in abundance and biomass between sampling dates with distance to oil platforms, stations were grouped based on distance to the nearest oil platform: $<3,3$ to 8 and $>8 \mathrm{~km}$ (see Table 2). The distances were chosen to approximate those at which various influences on macroinfauna have been previously detected in the North Sea studies (Olsgard \& Gray 1995) and also to maximise the number of samples within each group. A 2-factor ANOVA balanced design was applied to test for differences in mean values of abundance and biomass, as described in the previous section. To test the null hypothesis of no difference in assemblage composition, non-metric multidimensional scaling (MDS) ordination plots were produced using a ranked similarity matrix, based on Bray-Curtis similarity measures of fourth root-transformed macroinfauna family abundance and biomass data for both seasons. Differences in the macroinfauna assemblage composition for the $a$ priori distance from oil-related activities groupings were formally tested by a 2-way analysis of similarities (ANOSIM) (Clarke 1993) using an unbalanced design that included all the stations. Canonical analysis of principal coordinates (CAP) was used to contrast the results of the unconstrained ordination from the MDS against the constrained ordination produced by CAP, which seeks to separate samples based on an a priori hypothesis by looking for group differences along another dimensions. CAP also takes into account the correlation structure among the variables (families) in the abundance and biomass matrices (Anderson \& Willis 2003). Differences in the macroinfauna assemblage composition for the a priori distance groupings were formally tested by random permutation procedures. The index of multivariate dispersion (IMD) for each station group, and the relative dispersion of the groups, were calculated from the similarity matrices to explore the proposition that variability in community composition increases with increased levels of stress (Warwick \& Clarke 1993b). The relationship between assemblage composition and environmental variables was examined by the matching of Biotic to Environmental multivariate patterns (BIO-ENV) procedure (Clarke \& Ainsworth 1993). BIO-ENV uses a Spearman's rank correlation between the resulting ranked similarity matrices of fauna and correlation-based PCA of the normalised environmental variables. The analysis was performed using the same 10 variables used for the regression analysis. All the above univariate and multivariate routines were undertaken utilising the PRIMER (Plymouth Routines in Multivariate Ecological Research), GMAV5 for Windows and CAP software packages (Clarke \& Gorley 2001, Anderson 2003).

Regional comparison of pollution impact: A metaanalysis procedure was used to compare the macroinfauna assemblage response to oil-related disturbance in the southern Gulf of Mexico with a dataset from the north east (NE) Atlantic that considers a clear gradient of contamination and also includes various types of natural disturbances (Warwick \& Clarke 1993a). The meta-analysis comprises standardised measures of production $(P)$ at phylum level from the allometric equation $P=$ (biomass/abundance) $)^{0.73} \times$ abundance. Thus, abundance and biomass data from the study area were aggregated to phylum, combined to form the production matrix using the above formula, standardised and merged into the original database (supplied with the PRIMER software) before a MDS plot was produced (from fourth root-transformed data using the Bray-Curtis similarity index) for visual analysis. 


\section{RESULTS}

\section{Environmental analysis}

Pearson's product-moment correlation analysis was employed in order to identify common sources of oil and metals on the across- and along-shelf transects
(Table 1). On across-shelf transects, Fe, Mn, Zn and $\mathrm{Cu}$ were strongly associated with depth and grain size, similarly $\mathrm{Mn}, \mathrm{Zn}, \mathrm{Cu}$ and $\mathrm{Cr}$ were strongly associated with iron. These associations indicate a common source and distribution of these metals, with their concentrations related to increasing depth and smaller grain size. However TH, Ba and Ni were associated

Table 1. Pearson's product-moment correlation coefficients between pairs of natural and oil-related variables on (A, B) acrossshelf and $(C, D)$ along-shelf transects at each sampling date. Distplat = distance from nearest oil platform; $M G S=$ mean grain size; $\mathrm{TH}=$ total hydrocarbons. Significant coefficients are in bold

\begin{tabular}{|c|c|c|c|c|c|c|c|c|c|c|c|}
\hline & Depth & Distplat & MGS & $\mathrm{TH}$ & $\mathrm{Fe}$ & $\mathrm{Mn}$ & $\mathrm{Zn}$ & $\mathrm{Cu}$ & $\mathrm{Cr}$ & $\mathrm{Ba}$ & $\mathrm{Ni}$ \\
\hline \multicolumn{12}{|c|}{ (A) November 1999} \\
\hline Depth & 1 & & & & & & & & & & \\
\hline Distplat & -0.33 & 1 & & & & & & & & & \\
\hline MGS & 0.711 & -0.415 & 1 & & & & & & & & \\
\hline $\mathrm{TH}$ & 0.056 & -0.357 & 0.444 & 1 & & & & & & & \\
\hline $\mathrm{Fe}$ & 0.819 & -0.564 & 0.844 & 0.413 & 1 & & & & & & \\
\hline Mn & 0.802 & -0.592 & 0.841 & 0.399 & 0.974 & 1 & & & & & \\
\hline $\mathrm{Zn}$ & 0.855 & -0.545 & 0.806 & 0.343 & 0.974 & 0.944 & 1 & & & & \\
\hline $\mathrm{Cu}$ & 0.851 & -0.582 & 0.866 & 0.381 & 0.956 & 0.943 & 0.957 & 1 & & & \\
\hline $\mathrm{Cr}$ & 0.518 & -0.65 & 0.777 & 0.598 & 0.893 & 0.871 & 0.853 & 0.851 & 1 & & \\
\hline $\mathrm{Ba}$ & 0.007 & -0.723 & 0.448 & 0.549 & 0.387 & 0.401 & 0.362 & 0.445 & 0.659 & 1 & \\
\hline $\mathrm{Ni}$ & 0.376 & -0.173 & 0.189 & -0.332 & 0.195 & 0.19 & 0.271 & 0.193 & -0.049 & -0.093 & 1 \\
\hline \multicolumn{12}{|c|}{ (B) April 2000} \\
\hline Depth & 1 & & & & & & & & & & \\
\hline Distplat & -0.29 & 1 & & & & & & & & & \\
\hline MGS & 0.719 & -0.588 & 1 & & & & & & & & \\
\hline $\mathrm{TH}$ & 0.125 & -0.468 & 0.52 & 1 & & & & & & & \\
\hline $\mathrm{Fe}$ & 0.863 & -0.486 & 0.879 & 0.397 & 1 & & & & & & \\
\hline $\mathrm{Mn}$ & 0.857 & -0.501 & 0.89 & 0.434 & 0.978 & 1 & & & & & \\
\hline $\mathrm{Zn}$ & 0.786 & -0.559 & 0.892 & 0.436 & 0.942 & 0.934 & 1 & & & & \\
\hline $\mathrm{Cu}$ & 0.851 & -0.549 & 0.924 & 0.418 & 0.967 & 0.962 & 0.957 & 1 & & & \\
\hline $\mathrm{Cr}$ & 0.565 & -0.625 & 0.864 & 0.581 & 0.895 & 0.874 & 0.886 & 0.881 & 1 & & \\
\hline $\mathrm{Ba}$ & -0.04 & -0.628 & 0.557 & 0.806 & 0.312 & 0.327 & 0.439 & 0.399 & 0.615 & 1 & \\
\hline $\mathrm{Ni}$ & 0.572 & -0.069 & 0.532 & 0.322 & 0.537 & 0.6 & 0.514 & 0.573 & 0.398 & 0.177 & 1 \\
\hline \multicolumn{12}{|c|}{ (C) November 1999} \\
\hline Depth & 1 & & & & & & & & & & \\
\hline Distplat & 0.158 & 1 & & & & & & & & & \\
\hline MGS & 0.473 & -0.022 & 1 & & & & & & & & \\
\hline $\mathrm{TH}$ & 0.238 & -0.319 & 0.442 & 1 & & & & & & & \\
\hline $\mathrm{Fe}$ & 0.477 & -0.257 & 0.331 & 0.272 & 1 & & & & & & \\
\hline Mn & 0.393 & -0.366 & 0.233 & 0.277 & 0.961 & 1 & & & & & \\
\hline $\mathrm{Zn}$ & 0.479 & -0.25 & 0.422 & 0.397 & 0.918 & 0.911 & 1 & & & & \\
\hline $\mathrm{Cu}$ & 0.38 & -0.121 & 0.271 & 0.267 & 0.865 & 0.778 & 0.741 & 1 & & & \\
\hline $\mathrm{Cr}$ & 0.19 & -0.397 & 0.356 & 0.401 & 0.814 & 0.736 & 0.775 & 0.742 & 1 & & \\
\hline $\mathrm{Ba}$ & 0.135 & -0.557 & 0.204 & 0.531 & 0.359 & 0.415 & 0.466 & 0.305 & 0.47 & 1 & \\
\hline $\mathrm{Ni}$ & 0.249 & -0.035 & -0.026 & 0.146 & 0.359 & 0.465 & 0.364 & 0.16 & 0.025 & 0.049 & 1 \\
\hline \multicolumn{12}{|c|}{ (D) April 2000} \\
\hline Depth & 1 & & & & & & & & & & \\
\hline Distplat & 0.172 & 1 & & & & & & & & & \\
\hline MGS & 0.558 & -0.363 & 1 & & & & & & & & \\
\hline $\mathrm{TH}$ & 0.509 & -0.522 & 0.503 & 1 & & & & & & & \\
\hline $\mathrm{Fe}$ & 0.224 & -0.181 & 0.44 & 0.545 & 1 & & & & & & \\
\hline Mn & 0.286 & -0.396 & 0.561 & 0.681 & 0.918 & 1 & & & & & \\
\hline $\mathrm{Zn}$ & -0.001 & -0.092 & 0.264 & -0.013 & 0.188 & 0.123 & 1 & & & & \\
\hline $\mathrm{Cu}$ & 0.406 & -0.308 & 0.66 & 0.717 & 0.836 & 0.838 & 0.269 & 1 & & & \\
\hline $\mathrm{Cr}$ & -0.016 & 0.09 & 0.157 & 0.089 & 0.65 & 0.356 & 0.208 & 0.541 & 1 & & \\
\hline $\mathrm{Ba}$ & 0.112 & -0.628 & 0.444 & 0.591 & 0.218 & 0.245 & 0.15 & 0.433 & 0.274 & 1 & \\
\hline $\mathrm{Ni}$ & 0.04 & 0.072 & 0.052 & 0.059 & -0.188 & -0.193 & 0.047 & -0.016 & -0.048 & 0.302 & 1 \\
\hline
\end{tabular}


with neither depth nor grain size; therefore, their source and distribution may relate to some other variable. In the case of barium, moderate associations with distance to oil platforms and $\mathrm{TH}$ indicate that at least part of the barium might come from oil-related activities. This pattern of association is consistent on the across-shelf transects in both sampling periods. On the along-shelf transects, correlation coefficients among $\mathrm{Fe}, \mathrm{Mn}, \mathrm{Zn}, \mathrm{Cu}$ and $\mathrm{Cr}$ showed strong to moderate associations indicating a common source and distribution pattern, but this can not be explained solely on the base of depth, grain size or distance to oil platforms.

Table 2. Distance to the nearest oil platform for each sampled station, number of oil platforms located in a radius of $5 \mathrm{~km}$ from each sampled station, UCM percentage of oil hydrocarbons and fossil fuel pollution index (FFPI) per station and sampling date. TS = Transect Station, NS = not sampled. ${ }^{*}$ Concentrations of compounds below detection limit. Bold values indicate PAHs of petroleum origin

\begin{tabular}{|c|c|c|c|c|c|c|c|}
\hline \multirow[t]{2}{*}{ TS } & \multirow{2}{*}{ Depth (m) } & \multirow{2}{*}{$\begin{array}{c}\text { Nearest oil } \\
\text { platform (km) }\end{array}$} & \multirow{2}{*}{$\begin{array}{l}\text { Number of platforms } \\
\text { in } 5 \mathrm{~km} \text { radius }\end{array}$} & \multicolumn{2}{|c|}{ UCM \% } & \multicolumn{2}{|c|}{ FFPI } \\
\hline & & & & Nov 99 & Apr 00 & Nov 99 & Apr 00 \\
\hline A1 & 19 & 30 & 0 & 90 & 98 & 0.0 & 0.3 \\
\hline A2 & 21 & 22.5 & 0 & $*$ & 98 & 1.0 & 0.6 \\
\hline A3 & 22 & 15 & 0 & * & 97 & 0.9 & 1.0 \\
\hline A4 & 23 & 7.5 & 0 & * & 99 & 1.0 & 0.2 \\
\hline A5 & 25 & 4.4 & 2 & * & 99 & 0.0 & 0.8 \\
\hline A6 & 31 & 1.3 & 7 & * & 99 & 0.3 & 0.0 \\
\hline A7 & 38 & 1.3 & 8 & 100 & 100 & 0.0 & 0.1 \\
\hline A8 & 46 & 3.8 & 4 & 99 & 99 & 0.3 & 0.7 \\
\hline A9 & 63 & 2.5 & 2 & 99 & 98 & 0.0 & 1.0 \\
\hline A10 & 93 & 2 & 3 & 100 & 96 & 0.4 & 0.5 \\
\hline A11 & 116 & 6.3 & 0 & 97 & 100 & 0.1 & 0.2 \\
\hline A12 & 135 & 13.8 & 0 & 92 & 99 & 0.0 & 1.0 \\
\hline B1 & 12 & 0 & 0 & 96 & 94 & 0.1 & 1.0 \\
\hline $\mathrm{B} 2$ & 15 & 25.5 & 0 & 97 & 0 & 0.2 & 0.5 \\
\hline B3 & 22 & 16 & 0 & 74 & 98 & 0.1 & 0.4 \\
\hline B4 & 23 & 10 & 0 & 99 & 93 & 0.2 & 0.8 \\
\hline B5 & 27 & 2.5 & 1 & 88 & 0 & 0.6 & 0.4 \\
\hline B6 & 34 & 3.8 & 2 & 99 & 98 & 0.7 & 0.1 \\
\hline B7 & 41 & 2.5 & 5 & 99 & 75 & 0.0 & 0.4 \\
\hline B8 & 45 & 5.8 & 0 & 99 & 99 & 0.5 & 0.7 \\
\hline B9 & 52 & 2.5 & 4 & 100 & 100 & 0.3 & 0.9 \\
\hline B10 & 60 & 3.2 & 3 & 98 & 100 & 0.4 & 0.6 \\
\hline B11 & 87 & 5 & 1 & 98 & 95 & 0.1 & 0.0 \\
\hline B12 & 112 & 10 & 0 & 95 & 42 & 0.4 & 0.3 \\
\hline $\mathrm{C} 1$ & 37 & 15 & 0 & 98 & 97 & 0.0 & 0.3 \\
\hline $\mathrm{C} 2$ & 35 & 6.3 & 0 & 99 & 95 & 0.3 & 0.4 \\
\hline C3 & 32 & 2 & 4 & 99 & 96 & 0.4 & 0.3 \\
\hline $\mathrm{C} 4$ & 32 & 1.3 & 4 & 96 & 98 & 0.5 & 0.3 \\
\hline C5 & 30 & 1.3 & 7 & 99 & 99 & 0.8 & NS \\
\hline C6 & 32 & 2.5 & 8 & 97 & 99 & 0.7 & 0.2 \\
\hline $\mathrm{C} 7$ & 34 & 3.8 & 2 & 98 & 98 & 0.5 & NS \\
\hline C8 & 36 & 3.8 & 3 & 96 & 100 & 0.3 & 0.4 \\
\hline C9 & 38 & 11 & 0 & 99 & * & 0.3 & $*$ \\
\hline $\mathrm{C} 10$ & 39 & 16 & 0 & 99 & 99 & 0.3 & 0.0 \\
\hline C11 & 39 & 21.5 & 0 & 93 & 100 & 0.5 & 0.0 \\
\hline $\mathrm{C} 12$ & 39 & 28 & 0 & 99 & * & 0.4 & 0.0 \\
\hline D1 & 67 & 4.5 & 1 & 99 & 99 & 0.0 & 0.3 \\
\hline D2 & 52 & 8.8 & 0 & 107 & 99 & 0.4 & 0.7 \\
\hline D3 & 51 & 2 & 2 & 99 & 99 & 0.0 & 0.6 \\
\hline D4 & 46 & 3.8 & 4 & 100 & 99 & 0.2 & NS \\
\hline D5 & 46 & 3 & 5 & 100 & 98 & 0.0 & 0.0 \\
\hline D6 & 45 & 5.8 & 0 & 99 & 99 & 0.1 & NS \\
\hline D7 & 49 & 0.7 & 12 & 100 & 100 & 0.2 & 0.8 \\
\hline D8 & 48 & 3.8 & 3 & 64 & 98 & 0.2 & 0.7 \\
\hline D9 & 49 & 2.5 & 1 & 98 & 99 & 0.7 & 0.6 \\
\hline D10 & 49 & 11.3 & 0 & 98 & 99 & 0.2 & 1.0 \\
\hline D11 & 46 & 18.8 & 0 & 95 & 100 & 0.0 & $*$ \\
\hline D12 & 44 & 26.3 & 0 & 39 & 99 & 0.0 & * \\
\hline
\end{tabular}


Again barium showed moderate associations with $\mathrm{TH}$ and distance to oil platforms, and this pattern of association was consistent between sampling dates.

Oil hydrocarbons measured in this study showed that, at most of the stations, $>90 \%$ of the total hydrocarbons was an unresolved complex mixture (UCM), indicating a highly weathered and biodegraded petroleum origin. The fossil fuel pollution index demonstrated that 12 stations sampled in November 1999 and 19 stations sampled in April 2000 had PAHs of petroleum origin (Table 2). The metal most likely to have a terrigenous source, iron, showed a depth-related gradient and a pattern of decreasing concentration from SW to NE, moving away from the rivers' influence (Fig. 2). Thus, other metals were normalised for iron concentration, as iron is known to be a conservative element and its distribution along the transects demonstrated a pattern dictated by natural variation. There is evidence that suggests $\mathrm{TH}$ and barium are associated with distance to oil platforms, and because more than $90 \%$ of the $\mathrm{TH}$ presented in the samples corresponds to UCM, TH and barium will be used as a proxy for oil-related activities.
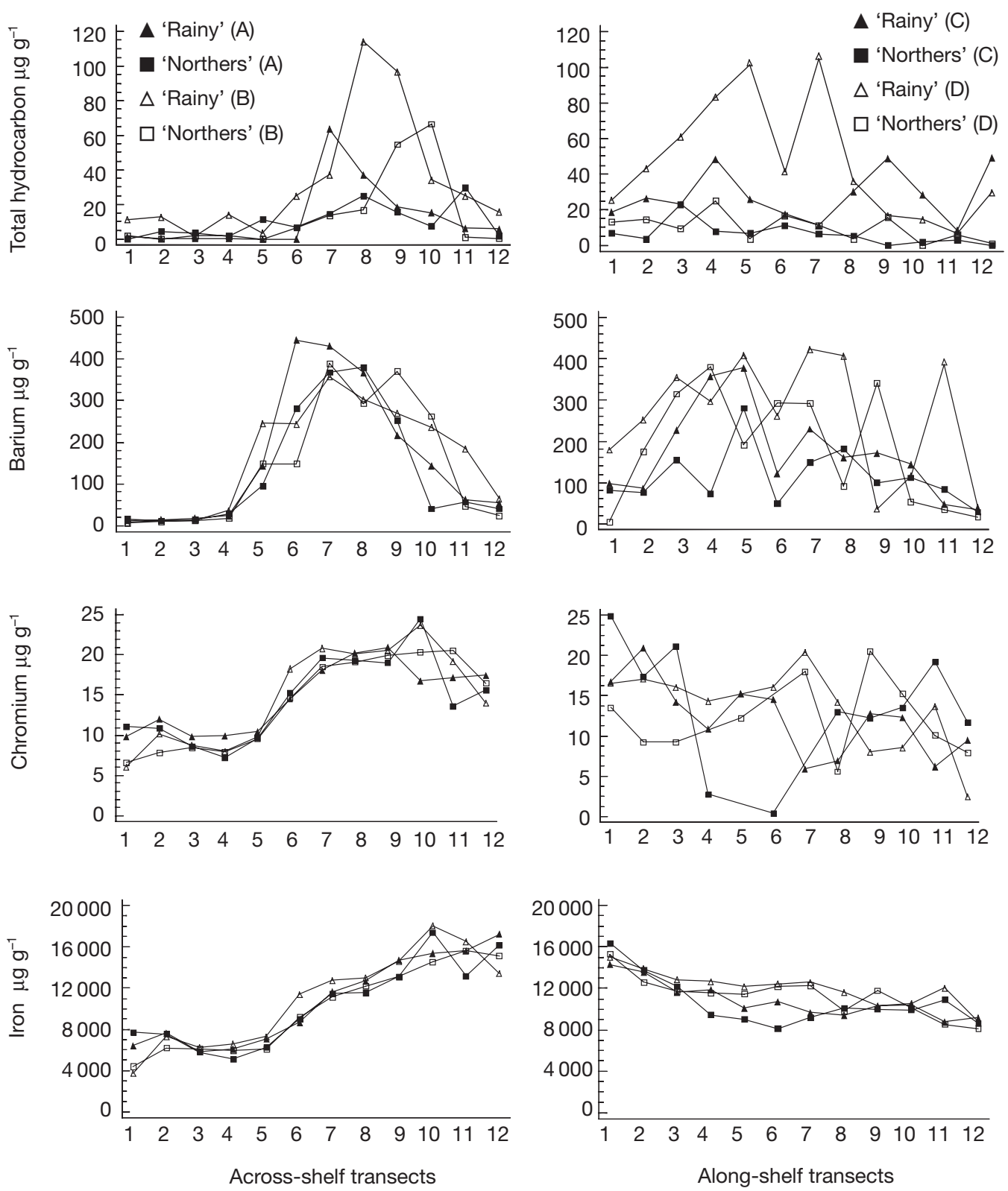

Fig. 2. Patterns of variables indicative of oil-related activity measured at each station on across-shelf (Transects A, B: left panels) and along-shelf transects (Transects C, D: right panels). Lines are provided as an aid to follow each transect. The region of oil activities corresponds to Stns 6 to 9 on across-shelf transects and Stns 3 to 8 on along-shelf transects 


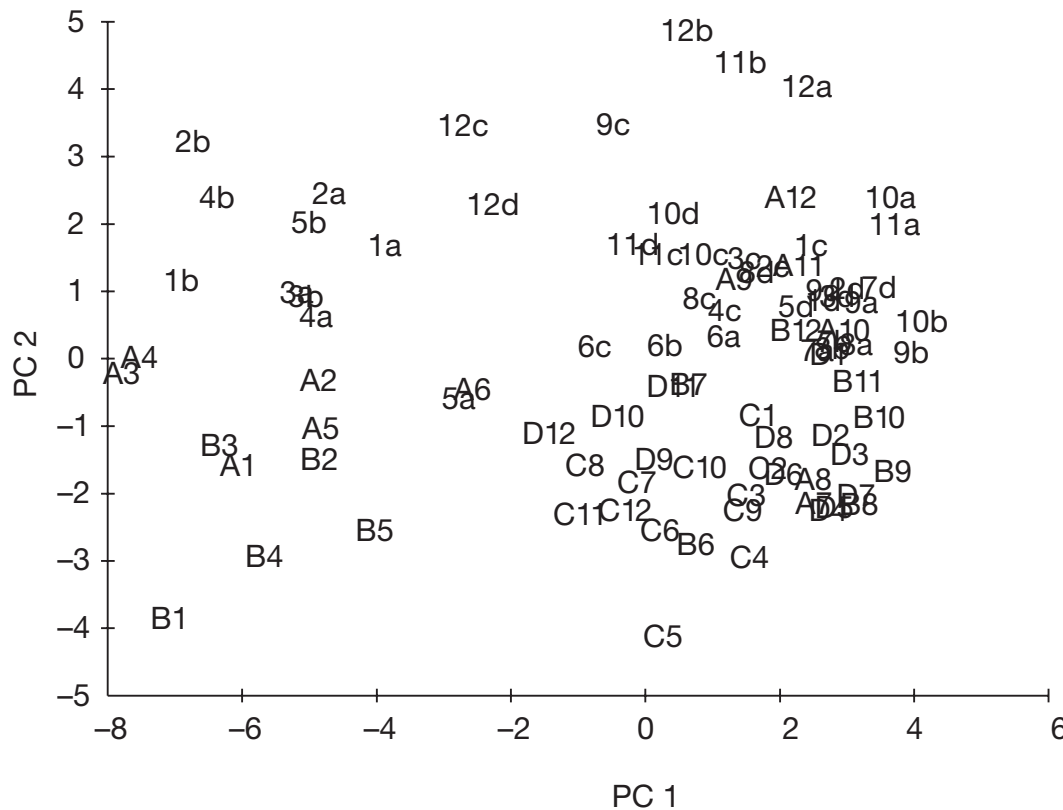

Fig. 3. PCA ordination plot of the 2 first PCs for 23 transformed environmental variables based on normalised euclidean distances by season. (A1 to D12 after the 'rainy' and 1a to $12 \mathrm{~d}$ after the 'northers season') weaker contribution of oil hydrocarbons that decreases in magnitude from the bottom to the top of the plot. The dominant variables on this axis appear to represent the temporal variation caused by the river runoff and associated sedimentation.

\section{Patterns of biota}

Across-shelf transects (Fig. 4) presented relatively high values and low variability of abundance, biomass and number of taxa at Stns A1 to 5 and B1 to 5 (<30 m deep). Values then decreased at Stns A6 to 12 and B6 to 12, except for Stn B8 where the highest abundance and number of taxa were recorded after the 'northers' season. Generally, Stns A6 to 12 and B6 to 12 were faunally impoverished and variability among these stations was high compared with stations $<30 \mathrm{~m}$ deep. On along-shelf transects (Fig. 4), values of abundance, biomass and number of taxa were as low
There were no indications of oil-related activities on the across-shelf transects at Stations A1 to 4 and B1 to 4 , which showed low concentrations of total hydrocarbons (TH) and barium below 20 and $40 \mu \mathrm{g} \mathrm{g}^{-1}$ of dry sediment respectively. These stations are located nearest to the coast with no oil-related activities and, in general, had the lowest concentrations of metals (Fig. 2). TH, barium and chromium showed peak concentrations between Stations A6 to 10 and B6 to 10 (maximum concentrations of 135, 446 and $24 \mu^{-1} \mathrm{~g}^{-1}$ of dry sediment respectively); these stations are located in the area of oil-related activity (Fig. 1). On the alongshelf transects, $\mathrm{TH}$, barium and chromium all showed no consistent pattern, but had relatively high and low values at stations close to and distant from oil fields respectively (Fig. 2).

The physical and chemical features of the sampled stations are summarised by the PCA of the 23 measured variables, including indicators of oil-related influence (Fig. 3). Principal component 1 (PC1) explains $47 \%$ of variation and the stations form 2 main clusters, related mainly to the increasing values (from left to right) of sediment metal load and decreasing sediment size, followed by a weaker contribution from oil hydrocarbons (Table 3). It is noticeable that oil hydrocarbons, barium and distance to oil platforms are not among the most influential variables, although their influence is stronger than depth. The second PC axis explains $15 \%$ of variation and is dominated by salinity, silt, clay and organic matter, followed by a
Table 3. Percentage of variation explained, plus coefficients, for the linear combination of 23 variables making up the first 2 principal components (PC) for 48 and 44 stations sampled after the 'rainy' and 'northers' seasons respectively. Bold numbers are coefficients for the most influential variables on each PC. UCM: unresolved complex mixture

\begin{tabular}{|lrr|}
\hline & PC1 & \multicolumn{1}{c|}{ PC2 } \\
\hline \% of variation & \multicolumn{1}{c}{} & \\
Variable/coefficients & & 15.3 \\
Depth (m) & 0.174 & 0.204 \\
Oil platforms (km) & -0.168 & 0.080 \\
Log salinity & 0.080 & $\mathbf{0 . 3 2 7}$ \\
Arc-sin \% sand & -0.216 & 0.208 \\
Arc-sin \% silt & 0.046 & $-\mathbf{0 . 4 3 0}$ \\
Arc-sin \% clay & 0.182 & $\mathbf{0 . 3 7 2}$ \\
Log surface area (m ${ }^{2}$ g m ${ }^{-1}$ ) & $\mathbf{0 . 2 6 3}$ & 0.092 \\
Moment mean (phi) & $\mathbf{0 . 2 6 9}$ & 0.022 \\
Moment sorting.(phi) & -0.131 & 0.172 \\
Arc-sin \% organic matter & 0.176 & $\mathbf{0 . 3 0 4}$ \\
Arc-sin \% carbonates & -0.242 & -0.219 \\
Log total hydrocarbons & -0.212 & -0.213 \\
Log total aliphatic & 0.193 & -0.228 \\
Log total aromatic & 0.200 & -0.181 \\
Log UCM aliphatic & 0.188 & -0.234 \\
Log UCM aromatic & 0.206 & -0.158 \\
Log iron & $\mathbf{0 . 2 7 5}$ & 0.061 \\
Log manganese & $\mathbf{0 . 2 7 4}$ & 0.104 \\
Log zinc & $\mathbf{0 . 2 6 0}$ & 0.090 \\
Log copper & $\mathbf{0 . 2 6 9}$ & 0.009 \\
Log chrome & $\mathbf{0 . 2 6 8}$ & 0.002 \\
Log barium & 0.205 & -0.177 \\
Log nickel & 0.006 & 0.189 \\
\hline
\end{tabular}



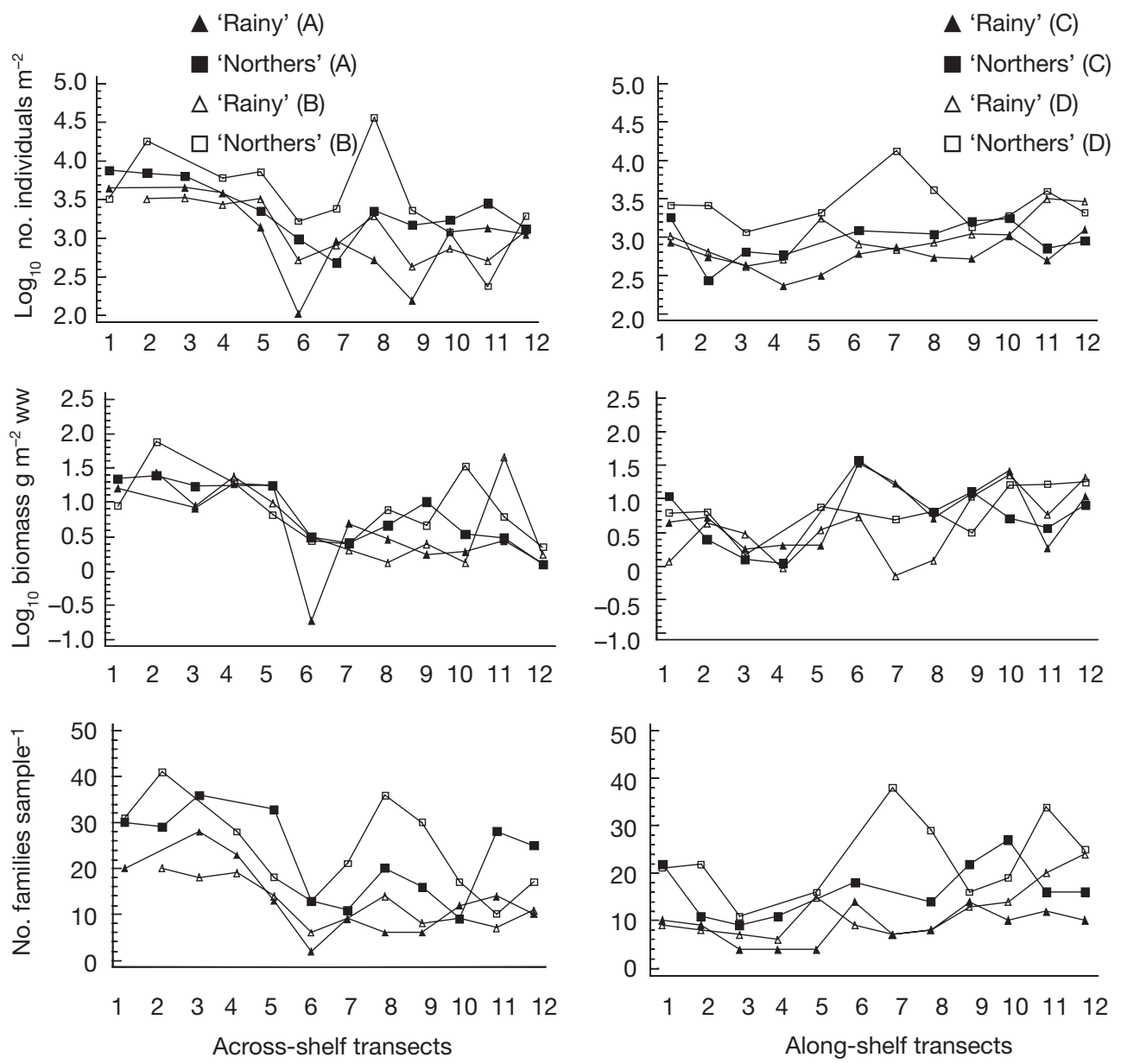

Fig. 4. Patterns of biological measures at each station on across-shelf transects A and B (left panels), and along-shelf transects C and D (right panels). ww: wet weight

as those recorded for Stns A6 to 12 and B6 to 12; however, there was no clear spatial pattern. In general, abundance and biomass were higher at most stations in samples taken after the 'northers' season than after the 'rainy' season. Number of taxa cannot be compared between sampling dates due to different sample size for the large macroinfauna fraction; nevertheless, an increase in number of taxa was observed when comparing only the small macroinfauna fraction.

\section{Influence of density and distance to oil platforms tested by univariate statistics}

Table 4 presents the results from the 2-factor ANOVA. For abundance data, statistical differences were evident between sampling dates and among densities and distance to oil platforms groups. For biomass, however, no statistical differences were found between sampling dates, only among densities and distance groups. Post-hoc Student-Newman-Keuls (SNK) tests showed that the 'high platform density' and the 'most distant' groups consistently had low mean values. Thus, the hypothesis of lower abundance and biomass in areas of high oil platform density and at stations close to oil platforms could not be rejected. Table 5 presents the best-fit models from regression analysis (statistically significant at $\mathrm{p}<0.05$ ) explaining the highest variation in $\log _{10}$ abundance and biomass in terms of 5 natural and 5 anthropogenic variables. After the 'rainy' season, 48 and $27 \%$ of the total variation in abundance and biomass respectively was explained by concentrations of chromium and barium. After the 'northers' season, however, chromium and organic matter content were the best explanatory variables for abundance and biomass respectively. From the scatterplots displayed in Fig. 5, it can be generally 
Table 4. Two-factor fixed-orthogonal ANOVA model testing for differences and interactions in macrobenthos abundance and biomass between 2 sampling dates for (a) 3 densities of oil rig/platforms (high, low and zero oil rigs within a $5 \mathrm{~km}$ radius) and (b) 3 groups of distance to the nearest oil platform ( $>8 \mathrm{~km}, 3$ to $8 \mathrm{~km}$ and 0 to $3 \mathrm{~km}$ ). Bold numbers indicate significant differences

\begin{tabular}{|lrrrrr|}
\hline Factor & SS & df & MS & $F$ & $\mathrm{p}$ \\
\hline (a) Abundance & & & & & \\
$\quad$ Season & 11.7276 & 1 & 11.7276 & 14.65 & $\mathbf{0 . 0 0 0 3}$ \\
Density of platforms & 9.3084 & 2 & 4.6542 & 5.81 & $\mathbf{0 . 0 0 4 9}$ \\
Season $\times$ density of platforms & 0.7501 & 2 & 0.3750 & 0.47 & 0.6283 \\
Residual & 48.0452 & 60 & 0.8008 & & \\
Total & 69.8313 & 65 & & & \\
Biomass & & & & & \\
Season & 1.9768 & 1 & 1.9768 & 1.63 & 0.2071 \\
Density of platforms & 9.8101 & 2 & 4.9051 & 4.04 & $\mathbf{0 . 0 2 2 7}$ \\
Season $\times$ density of platforms & 1.0063 & 2 & 0.5032 & 0.41 & 0.6629 \\
Residual & 72.9179 & 60 & 1.2153 & & \\
Total & 85.7111 & 65 & & & \\
(b) Abundance & & & & & \\
Season & 12.6677 & 1 & 12.6677 & 14.13 & $\mathbf{0 . 0 0 0 4}$ \\
Density of platforms & 11.2459 & 2 & 5.6230 & 6.27 & $\mathbf{0 . 0 0 3 4}$ \\
Season $\times$ density of platforms & 0.6608 & 2 & 0.3304 & 0.37 & 0.6933 \\
Residual & 53.7889 & 60 & 0.8965 & & \\
Total & 78.3633 & 65 & & & \\
Biomass & & & & & \\
Season & 1.4612 & 1 & 1.4612 & 1.90 & 0.1735 \\
Density of platforms & 9.6100 & 2 & 4.8050 & 6.24 & $\mathbf{0 . 0 0 3 5}$ \\
Season $\times$ density of platforms & 0.0134 & 2 & 0.0067 & 0.01 & 0.9913 \\
Residual & 46.2135 & 60 & 0.7702 & & \\
Total & 57.2981 & 65 & & & \\
& & & & & \\
\end{tabular}

pling dates, and among groups based on distance to oil platforms, showed significant differences in the main factors for both abundance and biomass data (Table 6). Differences in assemblage composition (as indicated by the Rvalue) were smaller between sampling dates than among distance groupings. Pairwise comparison indicated significant differences between the $>8 \mathrm{~km}$ versus the 3 to $8 \mathrm{~km}$ and 0 to $3 \mathrm{~km}$ groups, but no significant differences in assemblage composition between the latter 2 distance groupings.

Fig. 6c, d presents the 2D constrained CAP ordination plots for the same data used in the MDS analyses. It is clear from the plots that group differences existed but occurred along another dimension than those represented by MDS. Taking the correlation structure among the families into account provides a better definition of the influence of distance to the nearest oil platform on the community composition, in particular for the group of stations at 0 to $3 \mathrm{~km}$ and the April 2000 sampling period. Cross-validation of the station classification using the leave-one-out method with $m$ values of 7 and 16 indi-

noted that stations located in areas with high oil platform density present low values of abundance and biomass and high values of barium and chromium; the opposite is true for sites located in areas where oil platforms are absent. A shift in the relationship between organic matter and biomass between sampling dates is apparent (Fig. 5), as well as the lack of pattern in relation to oil platform density.

\section{Influence of distance to oil platform tested by multivariate statistics}

Fig. 6a, b presents the 2D MDS ordination plots for transformed abundance data using the grouping criteria of distance to the nearest oil platform for each season. The stress values are above 0.2 , indicating difficulty in representing the multivariate pattern in 2 dimensions. However, stations located at distances $>8 \mathrm{~km}$ from oil platforms appear to be more similar, whilst stations located at distances 3 to 8 and $<3 \mathrm{~km}$ from oil platforms do not show a clear grouping (rather they are distributed throughout the plot). MDS plots for biomass data displayed the same pattern and are therefore not shown. The 2-way ANOSIM test for differences between sam- cated a mis-classification of 52 and $41 \%$ for November and April respectively, with the highest degree of misclassification between groups 2 and 3 . The cumulative percentage of variation explained by the first principal coordinate axis was $64.8 \%$ for November $(m=7)$ and

Table 5. Models from stepwise multiple linear regression analyses that best explain variation in the observations for macroinfauna abundance and biomass (both $\log _{10}$ transformed) after the (a) 'rainy' and (b) 'northers' seasons

\begin{tabular}{|c|c|c|c|c|}
\hline \multirow[t]{2}{*}{ Predictor } & \multicolumn{2}{|c|}{ Abundance } & \multicolumn{2}{|c|}{ Biomass } \\
\hline & Coefficient & p-value & Coefficient & p-value \\
\hline \multicolumn{5}{|c|}{ (a) After 'rainy' season $(n=43)$} \\
\hline Constant & 5.06482 & $<0.0001$ & 1.94365 & $<0.0001$ \\
\hline Chromium & -1.20923 & 0.0163 & & \\
\hline Barium & -0.28966 & 0.0251 & -0.59497 & 0.0003 \\
\hline Regression & & $<0.0001$ & & 0.0003 \\
\hline $\mathrm{R}^{2}$ & 0.4842 & & 0.2709 & \\
\hline \multicolumn{5}{|c|}{ (b) After 'northers' season $(n=40)$} \\
\hline Constant & 5.14345 & $<0.0001$ & 1.53634 & $<0.0001$ \\
\hline Chromium & -1.5271 & 0.0017 & & \\
\hline \multicolumn{2}{|c|}{ Organic matter } & & -1.16645 & 0.0002 \\
\hline Regression & & 0.0017 & & 0.0002 \\
\hline $\mathrm{R}^{2}$ & 0.2247 & & 0.2993 & \\
\hline
\end{tabular}



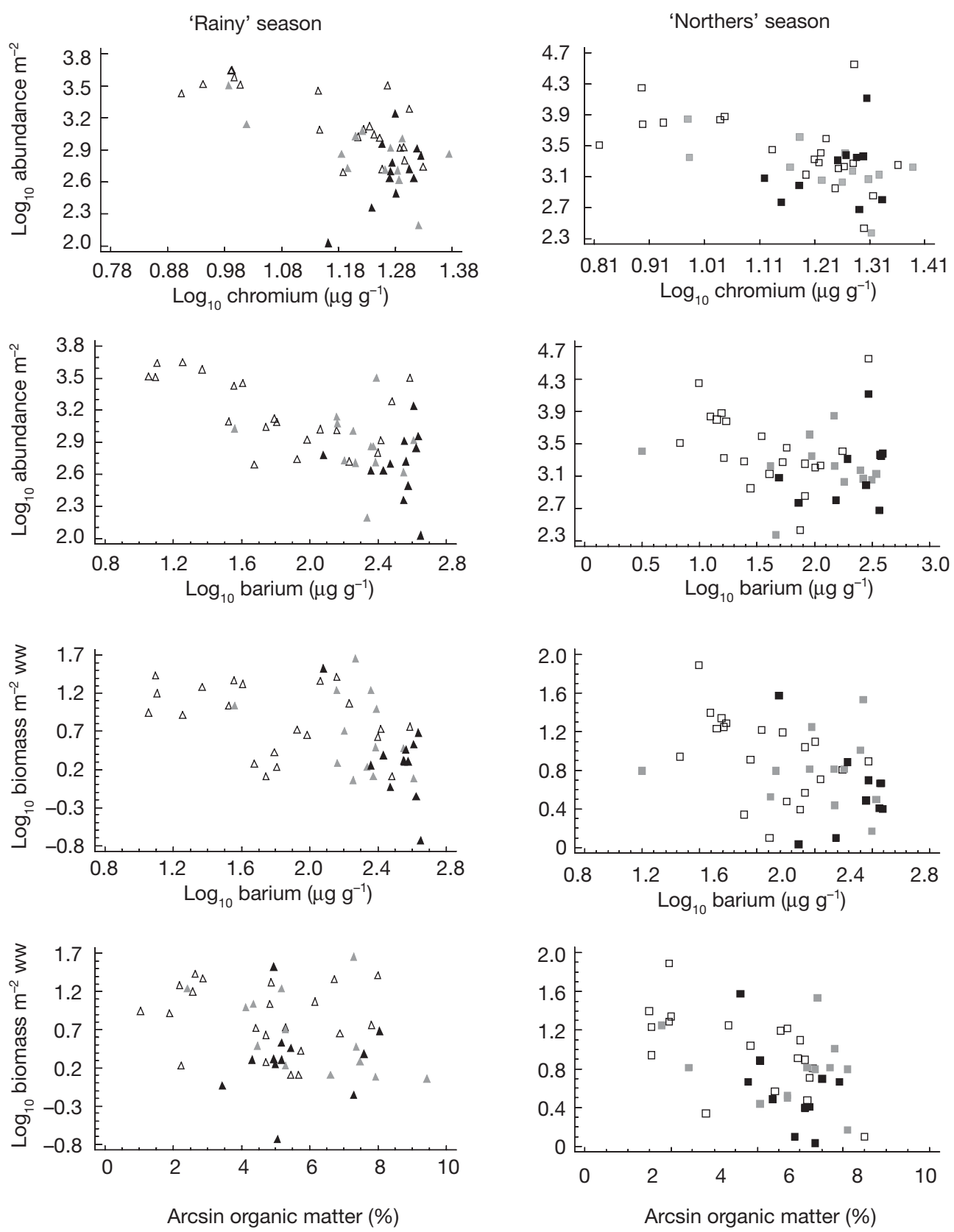

Fig. 5. Macroinfaunal abundance and biomass against environmental and oil-related variables selected as good descriptors from the multiple regression analysis. Left panels: after the 'rainy' season ( $\Delta$ : 0 oil rigs, $\Delta$ : 1 to 3 oil rigs, $\Delta 4$ to 12 oil rigs) and right panels: after the 'northers' season ( $\square: 0$ oil rigs, $=1$ to 3 oil rigs, $: 4$ to 12 oil rigs). ww: wet weight

$93 \%$ for April $(m=16)$. Despite the degree of mis-classification, the results of the permutation test indicated a significant difference in the composition and relative abundance of macroinfauna families among the 3 groups, based on distance to the nearest oil platform for both sampling dates (trace statistics $=0.586, \mathrm{p}=$ 0.0109 and delta- $1^{2}=0.459, \mathrm{p}=0.0058$ for November 1999 , and trace statistics $=1.222, \mathrm{p}=0.0031$ and delta$1^{2}=0.7798, p=0.0006$ for April 2000).
The following taxa had the highest positive individual correlations $(-0.4$ to -0.75$)$ with the first canonical axis for November 1999; polychaetes: Capitellidae, Cirratulidae, Goniadidae, Lumbrineridae, Spionidae; Mollusca: Corbulidae and Nemertea: Linneidae. All of them had their lowest abundances and biomass within the 0 to $3 \mathrm{~km}$ group. Only 2 taxa (Nephtyidae and Sergestidae) were restricted or had higher abundances in the 0 to $3 \mathrm{~km}$ group compared with the other 2, with 

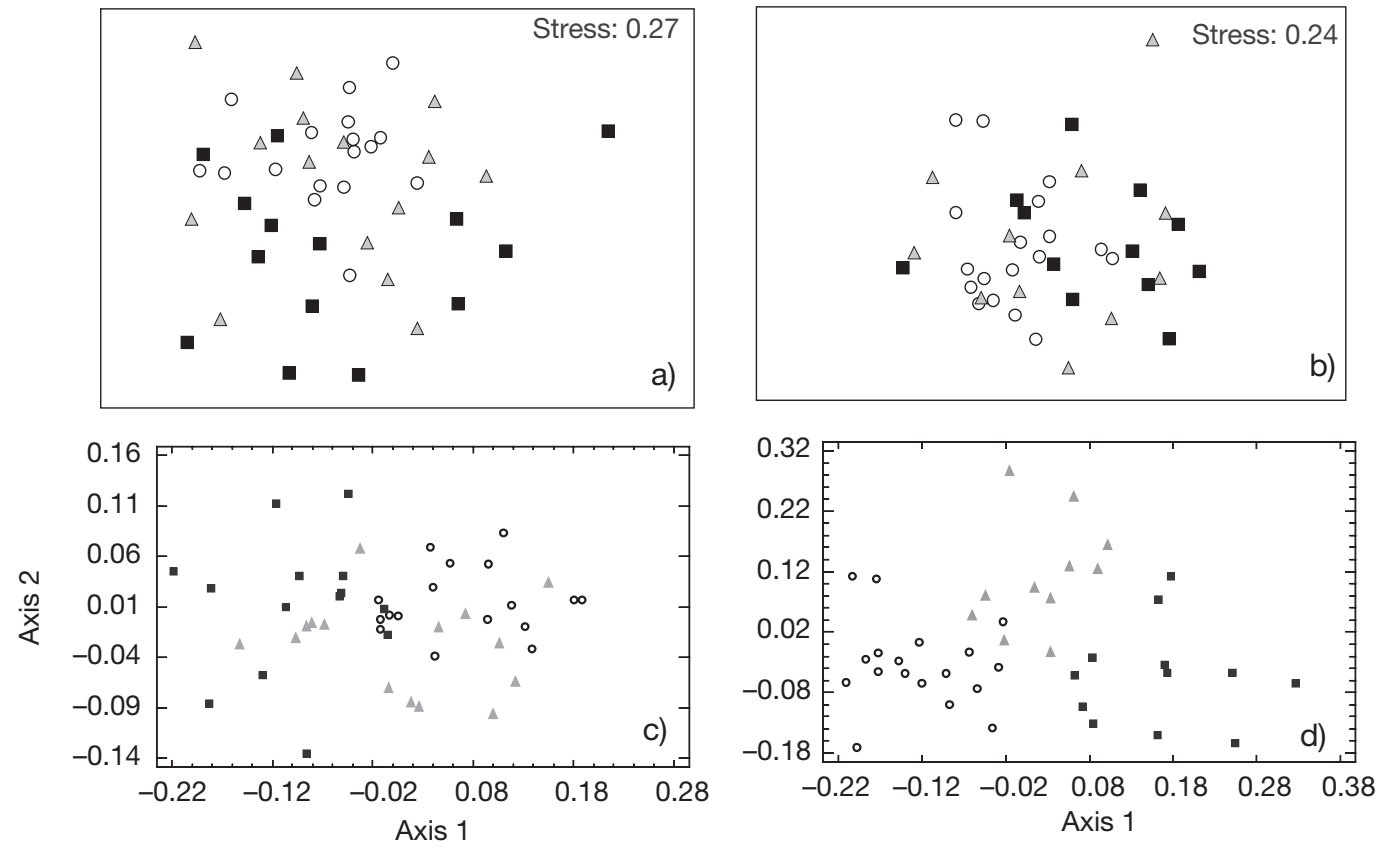

Fig. 6. (a, b) Two-dimensional MDS and (c, d) CAP ordination plots of assemblage data for macroinfauna (a, c) after the 'rainy' season and (b, d) after the 'northers' season, based on Bray-Curtis similarities of abundance (fourth root-transformed). Symbols represent groups of stations based on distance to the nearest oil field (O: $>8 \mathrm{~km}, \Delta: 3$ to $8 \mathrm{~km}, \mathbf{m}: 0$ to $3 \mathrm{~km})$

negative correlation coefficients of -0.3 to -0.4 . For April 2000, 7 families had negative correlation coefficients of -0.4 to -0.6 , and these taxa were; polychaetes: Capitellidae, Amphinomidae, Magelonidae, Onuphidae; Amphipoda: Ampeliscidae; Tanaidacea: Parapseudidade and Sipuncula: Aspidosiphonidae. These families were less abundant at the stations in the 0 to $3 \mathrm{~km}$ group, similar to the pattern previously observed in November.

Spearman's rank correlations between the similarity matrices of macroinfauna and PCA ordinations of a set of 10 variables using the BIOENV technique were generally low $\left(\mathrm{r}_{\mathrm{S}}<0.4\right.$, Table 7 ). Water depth was the best single explanatory variable for the multivariate configuration of abundance and biomass during both seasons, and the second best correlation included nickel. The degree of association was higher after the 'northers' season than after the 'rainy'.

Table 8 presents the results of the relative multivariate dispersion within, and pairwise comparisons between, distance groupings. The IMD within each group (for both sampling dates) showed a gradient increasing from stations nearest to an oil platform to those furthest away. Pairwise comparison of the IMD ratio values presented differences between sampling dates. After the 'rainy' and 'northers' seasons, similarities among samples from the $>8 \mathrm{~km}$ group were generally higher than among samples from the 3 to $8 \mathrm{~km}$ and 0 to $3 \mathrm{~km}$ distance groups, indicating higher variability within the latter groups. After the 'northers' season, the difference in the order of dispersion between the 3 to $8 \mathrm{~km}$ and 0 to $3 \mathrm{~km}$ distance groups was opposite to that observed after the 'rainy' season, although on both sampling dates the differences were small, as highlighted by the low IMD ratio value, indicating a similar degree of within-group variability.

\section{Regional comparison}

The results of using the phylum-level meta-analysis data to compare the severity of macroinfauna assemblage disturbances in the southern Gulf of Mexico to

Table 6. Two-way ANOSIM test for differences in macroinfauna assemblage composition between 'rainy' and 'northers' season and among groups based on distance to the nearest oil platform. Bold numbers indicate significant differences

\begin{tabular}{|lcccc|}
\hline & \multicolumn{2}{c}{ Abundance } & \multicolumn{2}{c|}{ Biomass } \\
& Global R & p-value & Global R & p-value \\
\hline $\begin{array}{l}\text { Season } \\
\begin{array}{l}\text { Distance to } \\
\text { oil platform }\end{array}\end{array}$ & $\mathbf{0 . 0 9 1}$ & 0.003 & $\mathbf{0 . 0 6 3}$ & 0.012 \\
Pairwise & & 0.001 & $\mathbf{0 . 1 5 7}$ & 0.001 \\
$>8 \mathrm{~km}, 3-8 \mathrm{~km}$ & $\mathbf{0 . 1 0 7}$ & 0.006 & $\mathbf{0 . 1 1 3}$ & 0.011 \\
$>8 \mathrm{~km}, 0-3 \mathrm{~km}$ & $\mathbf{0 . 2 8 7}$ & 0.001 & $\mathbf{0 . 2 8 1}$ & 0.001 \\
$3-8 \mathrm{~km}, 0-3 \mathrm{~km}$ & 0.051 & 0.09 & 0.052 & 0.084 \\
\hline
\end{tabular}


Table 7. Relationship between environmental variables and faunal assemblage composition using the BIO-ENV procedure. The combinations of 1 to 4 variables that best explain the faunal patterns based on abundance and biomass are given for each season. The coefficient $\left(r_{S}\right)$ is for Spearman's rank correlation, highest values are in bold. TH: total hydrocarbons

\begin{tabular}{|lccc|}
\hline \multicolumn{2}{|c|}{ Vabundance $\mathrm{r}_{\mathrm{S}}$} & Variables & \multirow{2}{*}{ Biomass $\mathrm{r}_{\mathrm{S}}$} \\
\hline (a) After the 'rainy' season & & & \\
Depth, Silt, TH, Nickel & 0.160 & Depth, Sorting, TH, Nickel & 0.137 \\
Depth, TH, Nickel & 0.176 & Depth, TH, Nickel & 0.144 \\
Depth, Nickel & $\mathbf{0 . 2 0 6}$ & Depth, Nickel & $\mathbf{0 . 1 8 8}$ \\
Depth & 0.147 & Nickel & 0.173 \\
(b) After the ‘northers' season & & \\
Depth, Iron, Barium, Nickel & 0.242 & Depth, Iron, Barium, Nickel & 0.291 \\
Depth, Iron, Nickel & 0.307 & Depth, Iron, Nickel & 0.353 \\
Depth, Nickel & 0.327 & Depth, Nickel & 0.376 \\
Depth & $\mathbf{0 . 3 4 8}$ & Depth & $\mathbf{0 . 4 0 4}$ \\
\end{tabular}

\section{DISCUSSION}

For any impact study of oil-related activities, the contamination (i.e. increased levels of a chemical compared to natural background levels, GESAMP 1995) status of the area needs to be determined in order to relate that contamination to changes in the fauna (Olsgard \& Gray 1995). Generally, in the southern Gulf of Mexico, the defined threshold for total hydrocarbons (TH) in unpolluted sediments is $70 \mu \mathrm{g} \mathrm{g}^{-1}$ dry weight and of biological origin (Botello et al. 1991, Gold-Bouchot et al. 1999). Botello et al. (1982) reported background levels of biogenic TH below that encountered in the NE Atlantic are shown in Fig. 7. Stations from the NE Atlantic (left of plot) are clearly separated from samples from the southern Gulf of Mexico (right of plot). The pollution gradient of the NE Atlantic samples is primarily along the vertical axis, going from unpolluted stations (U) at the bottom to grossly polluted (GP) stations at the top of the plots. The distribution of samples from the southern Gulf of Mexico along this pollution axis varied between seasons. The vast majority of stations were located under the moderate pollution condition after the 'rainy' season and there was no clear pattern in relation to distance to oil platforms. After the 'northers' season, a relationship with distance to oil platforms was apparent: the majority of stations from the $>8 \mathrm{~km}$ distance group were located under the unpolluted condition, and the stations from the remaining intermediate and closest distance groups were dispersed between the unpolluted to moderately polluted conditions.

Table 8. Relative dispersion and index of multivariate dispersion (IMD) of macroinfauna abundance data sampled after the 'rainy' and 'northers' seasons for groups based on distance to the nearest oil platform

\begin{tabular}{lcc} 
Distance to oil platform & 'Rainy' season & 'Northers' season \\
\hline Relative dispersion & & \\
$>8 \mathrm{~km}$ & 0.7 & 0.842 \\
$3-8 \mathrm{~km}$ & 1.13 & 1.088 \\
$0-3 \mathrm{~km}$ & 1.298 & 1.333 \\
Pairwise IMD & & \\
$>8 \mathrm{~km}, 3-8 \mathrm{~km}$ & -0.456 & -0.48 \\
$>8 \mathrm{~km}, 0-3 \mathrm{~km}$ & -0.57 & -0.257 \\
$3-8 \mathrm{~km}, 0-3 \mathrm{~km}$ & -0.206 & 0.272 \\
& & \\
\hline
\end{tabular}
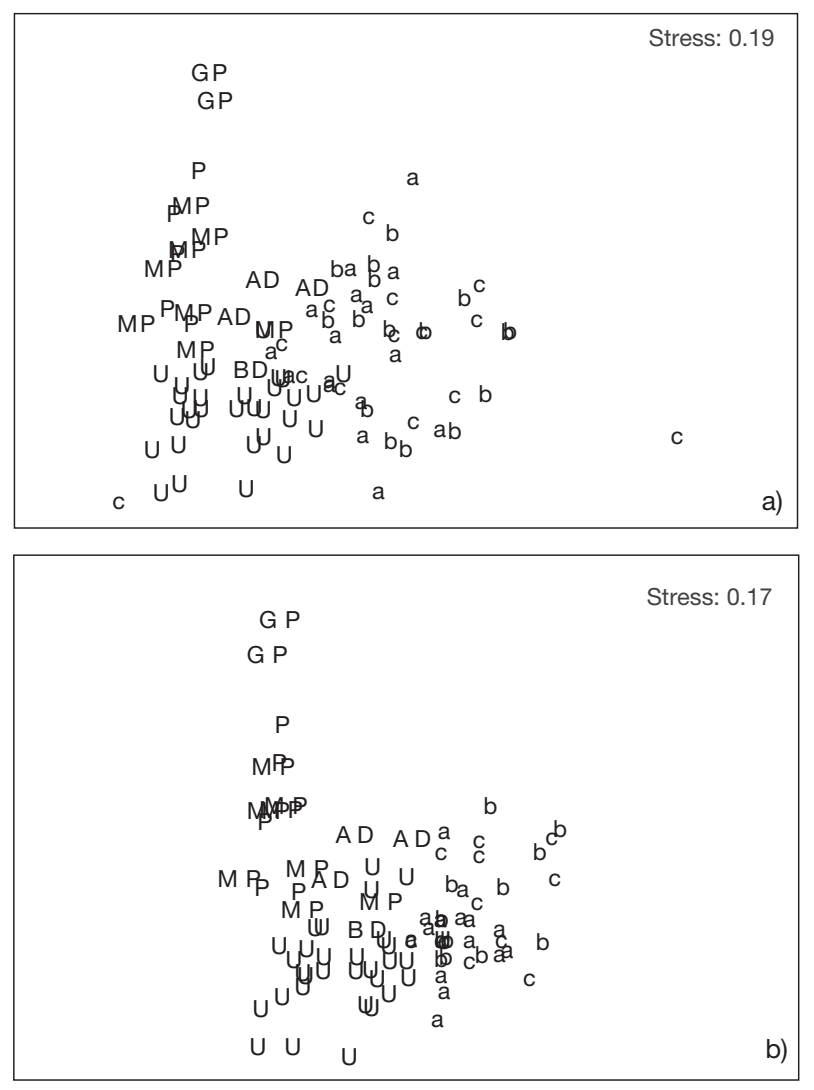

Fig. 7. Two-dimensional nMDS (non-metric multidimensional scaling) ordination plots of the meta-analysis of the NE Atlantic (GP: grossly polluted; P: polluted; MP: moderately polluted; U: unpolluted; BD: biodisturbed; $\mathrm{AD}$ : anoxic sites) and southern Gulf of Mexico data along transects A to D (a) after the 'rainy' and (b) after the 'northers' seasons, based on Bray-Curtis similarities of standardised production data (fourth root-transformed). Letters $\mathrm{a}, \mathrm{b}$ and $\mathrm{c}$ on ordinations represent groups of stations based on distance to the nearest oil platform ( $\mathrm{a}=>8 \mathrm{~km}, \mathrm{~b}=3$ to $8 \mathrm{~km}, \mathrm{c}=0$ to $3 \mathrm{~km})$ 
$50 \mu \mathrm{g} \mathrm{g}^{-1}$ in recent sediments of the 'transitional' region of the Campeche shelf. After the Ixtoc blowout in 1979, levels were above $100 \mu \mathrm{g} \mathrm{g}^{-1}$ of petroleum origin within the vicinity of the oil field (Boehm et al. 1982), returning to background levels after 12 months (Botello \& Villanueva 1987). The present study reports a range of concentrations from below detection limits at stations on the inner shelf to above $100 \mu \mathrm{g} \mathrm{g}^{-1}$ dry weight in the sediment at stations located within the oil production zone. Between 90 and $100 \%$ of the TH load was an unresolved complex mixture (UCM), indicating a chronic input of highly weathered petroleum (NAS 1985, Volkman et al. 1992). The fossil fuel pollution index also indicated a petroleum origin for PAHs (Boehm \& Farrington 1984) from 25 and $50 \%$ of the stations during November 1999 and April 2000 respectively.

There is no published background information on concentrations of trace metals in the southern Gulf of Mexico oil production zone and little is known about the amount of drilling fluids and produced water that have been discharged since oil exploration started in 1974. However, according to the environmental protection office of the Mexican oil company (PEMEX pers. comm.), there have been no direct discharges of oil-based drilling fluids or produced water to the water column or seabed. Considering the information available, it is therefore not possible to state how comparatively high the present concentrations of metals are. Previous work has highlighted increasing levels of metals towards the south and south-western portion of the Campeche Bank, mainly as a result of river runoff and fine sedimentation (Macias-Zamora et al. 1999). The results of the present study confirm that the increasing concentration of some metals, e.g. iron, in the transitional area of the Campeche shelf is indeed the result of river runoff and fine sedimentation. It has also been suggested that oil-related activities contribute to the concentrations of barium, nickel, chromium and vanadium (Rosales-Hoz et al. 1994, 1999). Levels of barium unequivocally indicate influence from drilling discharges (Kirkley 1984, Steinhauer et al. 1994, Rezende et al. 2002) and it has been previously demonstrated that barium levels in the sediment of the southern Gulf of Mexico increase from below detected levels to $>500 \mu \mathrm{g} \mathrm{g}^{-1}$ when approaching the oil production zone (Rosales-Hoz et al. 1994). The present study recorded similar values ranging from $<20 \mathrm{\mu g} \mathrm{g}^{-1}$ to a maximum of $446 \mu \mathrm{g} \mathrm{g}^{-1}$, with concentrations reaching a maximum at stations close to oil platforms. It appears that contamination from oilrelated activities extends beyond the immediate surroundings of the point source, as noted from the univariate plots of stations and indicators of oil-related activities in the present study. Additionally, results from the PCA clearly show that stations with high con- centrations of oil hydrocarbons and metals cluster together, independent of season, and do not follow the natural pattern of depth and grain-size gradients across and along the shelf. It is therefore concluded that the oil-impacted area in the southern Gulf of Mexico is comparatively extensive and thus differs from the apparent restriction of contamination to areas near the point source observed in the northern Gulf of Mexico (Middleditch 1981b, Kennicutt et al. 1996). Extensive contaminated areas and overlapping influences from neighbouring oil fields are expected from a long history of oil exploitation (Olsgard \& Gray 1995) and this seems to be the case for the present area of study.

Producing unequivocal evidence of pollution from offshore oil-related activities is a difficult task due to the pervasive effect of background variability linked to natural disturbance (Clark 1982, Spies 1987). Some possible results of oil disturbance on the benthic infauna were observed in the distribution of fauna along transects; faunally impoverished stations were located in areas where oil platforms are concentrated. A characteristic peak of opportunist taxa occurred at Stns B8 and D7, although several families of polychaetes that are known to contain opportunistic species had much higher abundances at stations where no oil activities were present (e.g. Lumbrineridae, Spionidae, Capitellidae, Cirratulidae), and were apparently subjected to natural disturbance as shown by the differences in abundances between sampling dates. Thus, the responses of opportunists to natural and anthropogenic disturbance were not easily distinguishable, perhaps as a consequence of the taxonomic level of identification for the fauna.

Overall, results from the present analyses showed that stations located in areas of high oil platform densities, or close to oil-related activities, had significantly lower abundance/biomass and different assemblage composition than those stations located in areas of low platform density or further away from oil-related activities. These effects were generally independent of natural differences between the sampling dates. The pattern of oil-related contamination partially explained the patterns in biotic variables as noted from the multiple regression analysis and the BIOENV procedure. However, the data were characterised by high levels of variability due, for example, to changes along depth gradients, the interaction of terrigenous and carbonaceous sediments (incorporating natural disturbance from river runoff) and winter storms supplementing the anthropogenic disturbance from oil-related activities. Variability in the natural pattern of macroinfauna assemblages could therefore be responsible for the lack of significant difference found between groups of stations at $<3 \mathrm{~km}$ and 3 to $8 \mathrm{~km}$ from oil platforms, and stations with relatively low and high oil platform densities in a $5 \mathrm{~km}$ radius. 
Although sediment characteristics in the area of study are relatively homogeneous in comparison to the northern portion of the Campeche Bank, which is characterised by grain-size intervals from silt to coarse sand (Hernandez-Arana et al. 2003), the range of disturbance from natural and oil-related sources is likely to account for much of the variability recorded for all biological variables. The IMD indicated an increased variability for the group of stations located within 0 to $3 \mathrm{~km}$ of an oil field, indicating increased levels of stress (Warwick et al. 1990, Warwick \& Clarke 1993b). The dispersion values for these stations resulted from the very low similarities in community composition, even between adjacent stations. This increased variability in the multivariate patterns can be explained by the documented response of infauna to both natural and oilrelated disturbance. Natural disturbance after the 'rainy' season produces an overall faunal impoverishment in the area, followed by a recovery when opportunist species dramatically increase in numbers after a lag of several months.

Despite the natural patchiness in relation to the effect of this disturbance, the temporal response of faunal impoverishment and the peak of opportunists are still driven mainly by the presence or absence of natural disturbance. Offshore oil-related disturbance is usually represented by a progressive degradation of the benthic community structure, and the response of opportunistic species is known to represent the final stages of pollution rather than being a recovery response to the absence of disturbance (Dicks \& Hartley 1982, Gillmor et al. 1985, Patin 1999). Faunal impoverishment resulting from natural disturbance is aggravated at stations close to oil fields or in areas of high oil rig density. Here the recovery response, as observed on the inner shelf following natural disturbance, is prevented by the continuous disturbance from oil-related activity. Therefore, when natural disturbance from the 'rainy' season is absent, it is suggested that oil-related disturbance controls the multivariate pattern of the macroinfauna, as noted from the analysis after the 'northers' season.

The presence of an environmental gradient (acrossshelf), and the lack of independent controls and previous information on assemblage composition of the area, required the use of alternative techniques that can overcome these problems and provide a means of determining the impact of oil-related activities on the macroinfauna over shelf and regional scales. The meta-analysis results were inconsistent between sampling dates, in terms of defining the status of stations close to the oil platforms with respect to a known pollution gradient from North Sea samples. However, what is clear from the results is a separation of the southern Gulf of Mexico samples from those of the NE
Atlantic. Such a partitioning has been previously reported with data obtained off Trinidad and Tobago (Agard et al. 1993) and southern Africa (Savage et al. 2001). Agard et al. (1993) proposed that this could be due to the estuarine character of their study site, which favoured a larger contribution to the estimated production matrix from crustaceans, but Savage et al. (2001) attributed the split to a greater contribution of molluscs and crustaceans that were physically robust and resistant to mining disturbance. In the southern Gulf of Mexico data, the separation of samples is due not only to crustaceans, but also to a greater contribution from nemerteans and sipunculids, unusual taxa in the other regions. The previous and present findings point to a limitation in the meta-analysis method proposed by Warwick \& Clarke (1993a). The polluted status of the NE Atlantic samples is based on the major contribution of annelids to the estimated production matrix, as this taxonomic group contains a great number of opportunistic species known to dwell in areas with organic enrichment (Warwick \& Clarke 1993a, 1994). However, on the Campeche shelf, several stations located in areas of high oil platform density, where annelids contribute little, were clustered with the unpolluted sites, particularly in the November 1999 sampling. This difference in the relative contribution of phyla could be driven by sediment differences between the 2 shelves, as the southern Gulf of Mexico is predominantly carbonate. In summary, this method highlights 2 points: (1) the difficulties of differentiating between natural and anthropogenic disturbance as reflected by the inconsistency of sample grouping between sampling dates, and (2) in the southern Gulf of Mexico, the community response to the interaction of natural and human disturbances is driven by the response of taxa in addition to polychaetes, linked perhaps to the carbonate nature of the area. It is proposed that to increase the applicability of the meta-analysis, more naturally disturbed samples (e.g. storm- and riverinfluenced stations) from a range of sediment types should be included in the database. Alternatively, it may be more valuable to create separate tropical and temperate data sets, where a phylum other than annelids controls the overall response.

The present study attempted to take into account the main sources of natural disturbance in the Campeche Shelf study area by sampling macroinfauna after the 'rainy' and 'northers' seasons, and to capture the putative oil-related influence by sampling over a range of sedimentary conditions. Despite the lack of adequate controls with which to compare the results, it is considered that there is enough evidence to conclude that oilrelated activities in the southern Gulf of Mexico are having a significant impact on the macroinfauna assemblages. 
Acknowledgements. The British Council and CONACYT (Mexico) are thanked for providing financial support through a scholarship to HAHA. Special thanks are due to D. Salas de Leon and E. Escobar-Briones for providing logistic support within the oceanographic research program PROMEBIO 2 and 3 (ICMyL UNAM, Mexico). Thanks are due to R. Hartley (Department of Geological Sciences, University of Plymouth, UK) for assistance in analysing data for sediment grain size and to V. Ceja, L. Sanchez, J. Dominguez and R. Castro (CINVESTAV, Merida, Mexico) for their help during the analyses of oil hydrocarbons and trace metals. The authors express their gratitude to the commander and crew of the oceanographic vessel 'B/O Justo Sierra' and the MSc students that provided help during the sampling program and onboard processing of samples. Two anonymous referees are thanked for their comments which contributed to the improvement of the final manuscript.

\section{LITERATURE CITED}

Addy JM, Hartley JP, Tibbetts PJC (1984) Ecological effects of low toxicity oil-based mud drilling in the Beatrice oilfield. Mar Pollut Bull 15:429-436

Agard JBR, Gobin J, Warwick RM (1993) Analysis of marine macrobenthic community structure in relation to pollution, natural oil seepage and seasonal disturbance in a tropical environment (Trinidad, West Indies). Mar Ecol Progr Ser 92:233-243

Anderson MJ (2003) CAP: a FORTRAN computer program for canonical analysis of principal coordinates. Department of Statistics, University of Auckland, Auckland

Anderson MJ, Willis TJ (2003) Canonical analysis of principal coordinates: a useful method of constrained ordination for ecology. Ecology 84:511-525

APHA (American Public Health Association) (1985). Standard methods for the analysis of water and wastewater, 16th edn. Washington, DC

Bello AA, Cano R (1991) Subsuelo marino en el area de la Sonda de Campeche. In: Soil mechanics and foundation engineering. Panamerican conference on soil mechanics and foundation engineering. Sociedad Chilena de Geotecnia, Viña del Mar, Chile, p 183-195

Boehm PD, Farrington JW (1984) Aspects of the polycyclic aromatic hydrocarbon geochemistry of recent sediments in the Georges Bank region. Environ Sci Technol 18: 840-845

Boehm PD, Fiest DL, Hausknecht K, Barbash J, Perry G (1982) Investigation of the transport and fate of petroleum hydrocarbons from the Ixtoc-I blowout in the Bay of Campeche - Sampling and analytical approaches. In: Keith LH (ed) Energy and environmental chemistry, Vol 1. Fossil fuels. Ann Arbor Science, MI, p 129-159

Boicourt WC, William JWJ, Valle-Levinson A, Atkinson LP (1998) Continental shelf of the southeastern United States and the Gulf of Mexico: In the shadow of the western boundary current. In: Robinson AR, Brink KH (eds) The sea. The global coastal ocean. Regional studies and syntheses, Vol 11. John Wiley and Sons, New York, p 135-181

Botello AV, Villanueva S (1987) Vigilancia de los hidrocarburos fosiles en sistemas costeros del Golfo de Mexico y areas adyacentes. I. Sonda de Campeche. An Inst Cienc Mar Limnol Univ Nac Auton Mex 14:45-52

Botello AV, Castro SA, Guerrero R (1982) Baseline studies for hydrocarbons and organic carbon isotope ratios of recent sediments in the Bank of Campeche before the Ixtoc-I oil spill. In: Keith LH (ed) Energy and environmental chem- istry, Vol 1 Fossil fuels. Ann Arbor Science, MI, p 119-128 Botello AV, Gonzalez C, Diaz G (1991) Pollution by petroleum hydrocarbons in sediments from continental shelf of Tabasco State, Mexico. Bull Environ Contam Toxicol 47: 565-571

Carney RS (1987) A review of study design for the detection of long-term environmental effects of offshore petroleum activities. In: Boesch DF, Rabalais NN (eds) Long-term environmental effects of offshore oil and gas development. Elsevier Applied Science, London, p 651-696

Clark RB (1982) The long-term effect of oil pollution on marine populations, communities and ecosystems: some questions. Philos Trans R Soc Lond B 297:185-192

Clarke KR (1993) Non-parametric multivariate analyses of changes in community structure. Aust J Ecol 18:117-143

Clarke KR, Ainsworth M (1993) A method of linking multivariate community structure to environmental variables. Mar Ecol Prog Ser 92:205-219

Clarke KR, Gorley RN (2001) PRIMER v5: User manual/ tutorial. PRIMER-E, Plymouth

Czitrom SPR, Ruiz F, Alatorre MA, Padilla AR (1986) Preliminary study of a front in the Campeche Bay, Mexico. In: Nihoul JCJ (ed) Marine interfaces ecohydrodynamics, Vol 42. Elsevier, Amsterdam, p 301-311

Daan R, Mulder M (1996) On the short-term and long-term impact of drilling activities in the Dutch sector of the North Sea. ICES J Mar Sci 53:1036-1044

Davies JM, Addy JM, Blackman RA, Blanchard JR and 5 others (1984) Environmental effects of the use of oilbased drilling muds in the North Sea. Mar Pollut Bull 15: 363-370

Dean WE Jr. (1974) Determination of carbonate and organic matter in calcareous sediments and sedimentary rocks by loss on ignition: comparison with other methods. J Sediment Petrol 44:242-248

Dicks B (1976) Offshore biological monitoring. In: Baker JM (ed) Marine ecology and oil pollution. Applied Science Publishers, Barking, p 325-440

Dicks B, Hartley JP (1982) The effects of repeated small oil spillages and chronic discharges. Philos Trans R SocLond B 297:285-307

Ellis JI, Schneider DC (1997) Evaluation of a gradient sampling design for environmental impact assessment. Environ Monit Assess 48:157-172

Ferraro SP, Cole FA (1992) Taxonomic level sufficient for assessing a moderate impact on macrobenthic communities in Puget Sound, Washington, USA. Can J Fish Aquat Sci 49:1184-1188

Fuentes-Yaco C, Salas de Leon DA, Monreal-Gomez MA, Vera-Herrera F (2001) Environmental forcing in a tropical estuarine ecosystem: the Palizada river in the southern Gulf of Mexico. Mar Freshw Res 52:735-744

GESAMP (Group of Experts on the Scientific Aspects of Marine Environmental Protection) (1995) Biological indicators and their use in the measurement of the condition of the marine environment. Report No. 55, United Nations Environment Programme, Nairobi

Gillmor RB, Menzie CA, Mariani GM, Levin DR, Ayers RC, Sauer TC Jr. (1985) Effects of exploratory-drilling discharges on the benthos. In: Duedall IW, Kester DA, Park PK, Ketchum BH (eds) Energy wastes in the ocean, Vol 4. John Wiley \& Sons, New York, p 243-270

Gold-Bouchot G, Zapata-Perez O, Noreña-Barroso E, CejaMoren V, Zavala-Coral M (1999) Oil pollution in the southern Gulf of Mexico. In: Kumpf H, Steidinger K, Sherman K (eds) The Gulf of Mexico large marine ecosystem assessment, sustainability and management. Blackwell 
Scientific, Malde, MA, p 372-381

Gonzalez-Macias C (1989) Las comunidades bentonicas y su relacion con afloramientos naturales de hidrocarburos en el Golfo de Mexico: Crucero Chapo I. Universidad y Ciencia 6:7-28

Gray JS, Clarke KR, Warwick RM, Hobbs G (1990) Detection of initial effects of pollution on marine benthos: an example from the Ekofisk and Eldfisk oilfields, North Sea. Mar Ecol Prog Ser 66:285-299

Green RH, Montagna P (1996) Implications for monitoring: study designs and interpretation of results. Can J Fish Aquat Sci 53:2629-2636

Gutierrez-Estrada M, Galaviz-Solis A (1991) Clasificacion binaria de los sedimentos superficiales del suroeste del Golfo de Mexico. Jaina 2:6

Hartley JP (1984) The benthic ecology of the Forties oilfield (North Sea). J Exp Mar Biol Ecol 80:161-195

Hernandez Arana HA (2003) Influence of natural and anthropogenic disturbance on the soft bottom macrobenthic community of the Campeche Bank, Mexico. PhD thesis, University of Plymouth, Plymouth

Hernandez Arana HA, Rowden AA, Attrill MJ, Warwick RM, Gould-Bouchot G (2003) Large-scale environmental influences on the benthic macroinfauna of the southern Gulf of Mexico. Est Coast Shelf Sci 58:825-841

Holme NA, McIntyre AD (1984) Methods for the study of marine benthos. Blackwell Scientific Publications, Oxford

Kennicutt MC II, Boothe PN, Wade TL, Sweet ST and 5 others (1996) Geochemical patterns in sediments near offshore production platforms. Can J Fish Aquat Sci 53:2554-2566

Kingston PF (1992) Impact of offshore oil production installations on the benthos of the North Sea. ICES J Mar Sci 49: 45-53

Kirkley C (1984) Drilling mud. Division of Continuing Education. University of Texas at Austin, Houston, TX

Lizarraga-Partida ML, Izquierdo-Acuña FB, Chang IW (1991) Marine bacteria on the Campeche Bank oil field. Mar Pollut Bull 22:401-405

Macias-Zamora JV, Villaescusa-Celaya JA, Muñoz-Barbosa A, Gold-Bouchot G (1999) Trace metals in sediment cores from the Campeche shelf, Gulf of Mexico. Environ Pollut 104:69-77

Middleditch BS (1981a) Environmental effects of offshore oil production. The Buccaneer gas and oil field study. Plenum Press, New York

Middleditch BS (ed) (1981b) Hydrocarbons and sulphur. In:Middleditch BS (ed) Environmental effects of offshore oil production. Plenum Press, New York, Houston, Texas, p 15-54

Monreal-Gomez MA, Salas de Leon DA, Padilla-Pilotze AR, Alatorre-Mendieta MA (1992) Hydrography and estimation of density currents in the southern part of the Bay of Campeche, Mexico. Cienc Mar 18:115-133

Montagna P, Harper DE Jr. (1996) Benthic infaunal long-term response to offshore production platforms in the Gulf of Mexico. Can J Fish Aquat Sci 53:2567-2588

NAS (National Academy of Science) (1985) Oil in the sea: inputs, fates and effects. National Academy of Science, Washington, DC

Olsgard F, Gray JS (1995) A comprehensive analysis of the effects of offshore oil and gas exploration and production on the benthic communities of the Norwegian continental shelf. Mar Ecol Prog Ser 122:277-306

Patin S (1999) Environmental impact of the offshore oil and gas industry. Ecomonitor publishing, New York

Rabalais NN, McKee BA, Reed DJ, Means JC (1992) Fate and effects of produced water discharges in coastal Louisiana,
Gulf of Mexico, USA. In: Ray JP, Engelhart FR (eds) Produce water. Plenum Press, New York, p 355-369

Rezende CE, Lacerda LD, Ovalle ARC, Souza CMM, Gobo AAR, Santos DO (2002) The effect of an oil drilling operation on the trace metal concentrations in offshore bottom sediments of the Campos Basin oilfield, SE Brazil. Mar Pollut Bull 44:680-684

Rosales-Hoz L, Carranza-Edwards A, Mendez-Jaime C, Monreal-Gomez MA (1999) Metals in shelf sediments and their association with continental discharges in a tropical zone. Mar Freshw Res 50:189-196

Rosales-Hoz L, Carranza-Edwards A, Santiago-Perez S, Mendez-Jaime C, Doger-Badillo R (1994) Study of anthropogenically induced trace metals on the continental shelf in the southeastern part of the Gulf of Mexico. Rev Int Contam Ambient 10:9-13

Santiago J, Baro A (1992) Mexico's giant fields, 1978-1988 decade. Am Assoc Pet Geol Mem 54:73-99

Savage C, Field JG, Warwick RM (2001) Comparative metaanalysis of the impact of offshore marine mining on macrobenthic communities versus organic pollution studies. Mar Ecol Prog Ser 221:265-275

Secretaría de Marina (1994) Carta nautica S. M. 840 Bahía de Campeche. Direccion General de Oceanografia Naval, Mexico

Sericano JL, Atlas EL, Wade TL, Brooks JM (1990) NOAA's status and trend mussel watch program: Chlorinated pesticides and PCBs in oysters (Crassostrea virginica) and sediments from the Gulf of Mexico, 1986-1987. Mar Environ Res 29:161-203

Sokal RR, Rohlf FJ (1995) Biometry. W. H. Freeman and Company, New York

Somerfield PJ, Clarke KR (1995) Taxonomic levels, in marine community studies, revisited. Mar Ecol Prog Ser 127: 113-119

Soto LA, Escobar-Briones E (1995) Coupling mechanisms related to trophic benthic production in the SW Gulf of Mexico. In: Eleftheriou A, Ansell AD, Smith CJ (eds) Proc 28th Eur Mar Biol Symp. Institute of Marine Biology of Crete, Iraklio, Crete. Olsen and Olsen, Fredensborg, p 233-242

Soto LA, Gracia A (1987) Evaluacion de los efectos de hidrocarburos fosiles sobre las poblaciones de camarones peneidos en el Banco de Campeche. An Inst Cienc Mar Limnol Univ Nac Auton Mex 14:133-146

Spies RB (1987) The biological effects of petroleum hydrocarbons in the sea: assessments from the field and microcosms. In: Boesch DF, Rabalais NN (eds) Long-term environmental effects of offshore oil and gas development. Elsevier Applied Science, London, p 411-467

Steinhauer M, Crecelius E, Steinhauer W (1994) Temporal and spatial changes in the concentrations of hydrocarbons and trace metals in the vicinity of an offshore oil-production platform. Mar Environ Res 37:129-163

UNEP/IOC/IAEA (1992) Determination of petroleum hydrocarbons in sediments. Reference methods for marine pollution studies. Report No. 20, United Nations Environment Programme

Valdes VM, Ortega Ramirez R (2000) Issues and challenges in the requalification of offshore platforms in Mexico. J Offshore Mech Arct Eng 122:65-71

Vazquez F, Rangel R, Quintero-Marmol AM, Fernandez J, Aguayo E, Palacio A, Sharma VK (2000) Southern Gulf of Mexico. In: Sheppard CRC (ed) Seas at the millennium: an environmental evaluation, Vol 1. Elsevier Science, Amsterdam, p 467-482

Vidal VMV, Vidal VF, Hernandez FA, Meza E, Zambrano L 
(1994) Winter water mass distributions in the western Gulf of Mexico affected by a colliding anticyclonic ring. J Oceanogr 50:559-588

Volkman JK, Holdsworth DG, Neill GP, Bavor HJ Jr. (1992) Identification of natural, anthropogenic and petroleum hydrocarbons in aquatic sediments. Sci Total Environ 112: 203-219

Warwick RM, Clarke KR (1993a) Comparing the severity of disturbance: a meta-analysis of marine macrobenthic community data. Mar Ecol Prog Ser 92:221-231

Warwick RM, Clarke KR (1993b) Increased variability as a symptom of stress in marine communities. J Exp Mar Biol Ecol 172:215-226

Editorial responsibility: John Gray (Contributing Editor), Oslo, Norway
Warwick RM, Clarke KR (1994) Relearning the ABC: Taxonomic changes and abundance/biomass relationships in disturbed benthic communities. Mar Biol 118:739-744

Warwick RM, Clarke KR, Suharsono (1990) A statistical analysis of coral community responses to the 1982-83 El Niño in the Thousand Islands, Indonesia. Coral Reefs 8:171-179

Wolfe KJ, Michibayashi K (1995) 'Basic' entropy grouping of laser derived grain-size data: an example from the great barrier reef. Comput Geosci 21:447-462

Yañez-Arancibia A, Sanchez-Gil P (1983) Environmental 'behavior' of Campeche Sound ecological system, off Terminos Lagoon, Mexico: preliminary results. An Inst Cienc Mar Limnol Univ Nac Auton Mex 10:117-136

Submitted: May 6, 2004; Accepted: October 6, 2004 Proofs received from author(s): March 8, 2005 